Research article

urn:1sid:zoobank.org:pub:638FB522-533A-4EF7-9582-2E0ADF798777

\title{
High diversity and endemism in the genus Cautires Waterhouse, 1879 (Coleoptera: Lycidae) from the Malay mountain forests, with the descriptions of fourteen new species
}

\author{
Alice JIRUSKOVA ${ }^{1}$, Michal MOTYKA ${ }^{2} \&$ Ladislav BOCAK ${ }^{3, *}$ \\ ${ }^{1,2,3}$ Department of Zoology, Faculty of Science, Palacky University, 17. listopadu 50, \\ 77146 Olomouc, Czech Republic. \\ ${ }^{1}$ Email: alice.jiruskova@seznam.cz \\ ${ }^{2}$ Email: michal.motyka@upol.cz \\ *corresponding author: ladislav.bocak@upol.cz \\ ${ }^{1}$ urn:Isid:zoobank.org:author:E8EA3180-2399-4EA9-86BD-DBFC381E2F93 \\ ${ }^{2}$ urn:1sid:zoobank.org:author:242DF8C7-1E68-45F7-AD24-C4BC0C5D0D94 \\ ${ }^{3}$ urn:1sid:zoobank.org:author:78383404-FF9F-46EA-A1AE-ACF3613E1D69
}

\begin{abstract}
We identified a high diversity in the net-winged beetles of the genus Cautires in Peninsular Malaysia. Fourteen new species are described: Cautires alexae sp. nov., C. andujari sp. nov., C. arribasae sp. nov., C. berembanensis sp. nov., C. campestris sp. nov., C. communis sp. nov., C. jasarensis sp. nov., C. katarinae sp. nov., C. kirstenae sp. nov., C. kotatinggensis sp. nov., C. linardi sp. nov., C. maseki sp. nov., $C$. pahangensis sp. nov. and $C$. renatae sp. nov. Seven previously described species are discussed, illustrated and differential diagnoses provided; all species are keyed. The Cautires species differ in a limited number of diagnostic characters, namely in the shape of male antennae, the relative size of eyes and in the shape of the male genitalia. The females are difficult to assign to a conspecific male due to high intraspecific variability. The characteristically low dispersal propensity of net-winged beetles lead to the evolution of the unique fauna in the Malay mountains and despite an extensive study of the type material we recorded only a single species of Cautires occurring simultaneously in Sumatra. We suggest that the Malay mountain fauna is highly endemic and evolved in situ.
\end{abstract}

Keywords. Taxonomy, morphology, Sundaland, Oriental Region, new species.

Jiruskova A., Motyka M. \& Bocak L. 2016. High diversity and endemism in the genus Cautires Waterhouse, 1879 (Coleoptera: Lycidae) from the Malay mountain forests, with the descriptions of fourteen new species. European Journal of Taxonomy 219: 1-29. http://dx.doi.org/10.5852/ejt.2016.219

\section{Introduction}

The high diversity of beetles in tropical regions remains poorly studied and the number of undescribed taxa in the randomly collected samples is often substantially higher than the number of known species. Such lack of knowledge is to be expected in relation to under-investigated and long-inaccessible regions such as New Guinea (Riedel et al. 2013; Bocek \& Bocak 2016), but, at least in the case of net-winged 
beetles (Lycidae), we can find a high proportion of undescribed taxa in the whole tropics. This is also true for areas where entomological research has a long tradition, such as Sulawesi (Bocak 2000), the Philippines (Weiszenstein \& Bocak 2011) and the Great Sundas (Masek et al. 2015). The recent DNA-based study dealing with the Cautires obsoletus species group, i.e., the former genus Bulenides Waterhouse, 1879 (Jiruskova \& Bocak 2015), revealed quite a high number of unknown species, as was also the case in recently collected material from the Malay Peninsula. This region was intensively studied from the late $19^{\text {th }}$ century until WWII (Waterhouse 1879; Pic 1925, Kleine 1930a, b, 1933), but has since been omitted from studies.

The Cautires is placed in the tribe Metriorrhynchini, which is the largest lineage of Lycidae as regards the number of species (1200 spp. in 41 genera in the Old World tropics, Kleine 1933; Sklenarova et al. 2013) and which, along with Platerodini, is the most common group of net-winged beetles in the Orient. Almost 100 species of Cautires have been reported from Sundaland (Kleine 1933; Bocak 2002), whereas the recent molecular study dealing with the delimitation of genera in Metriorrhynchini has shown that the fauna of Sumatra, Borneo and the Malay Peninsula seldom share any common species and that even the mountain ranges within a single island have a highly endemic fauna (Sklenarova et al. 2014). The species' high turnover is supposedly a result of biological characteristics of net-winged beetles. Lycidae live under the canopy and, although winged and capable of flight, they have a tendency to remain in the low strata of the forest and do not disperse easily. The low dispersal propensity of net-winged beetles leads to diversification in situ and limited dispersal between islands or mountain ranges (Li et al. 2015; Masek et al. 2015). Cautires larvae mainly evolve on the ground in wood at various stages of decomposition. They suck liquids with rich microbial life from small-size organic detritus such as rotten twigs. They can be collected from under the bark of dead tree trunks (Bocak \& Matsuda 2003).

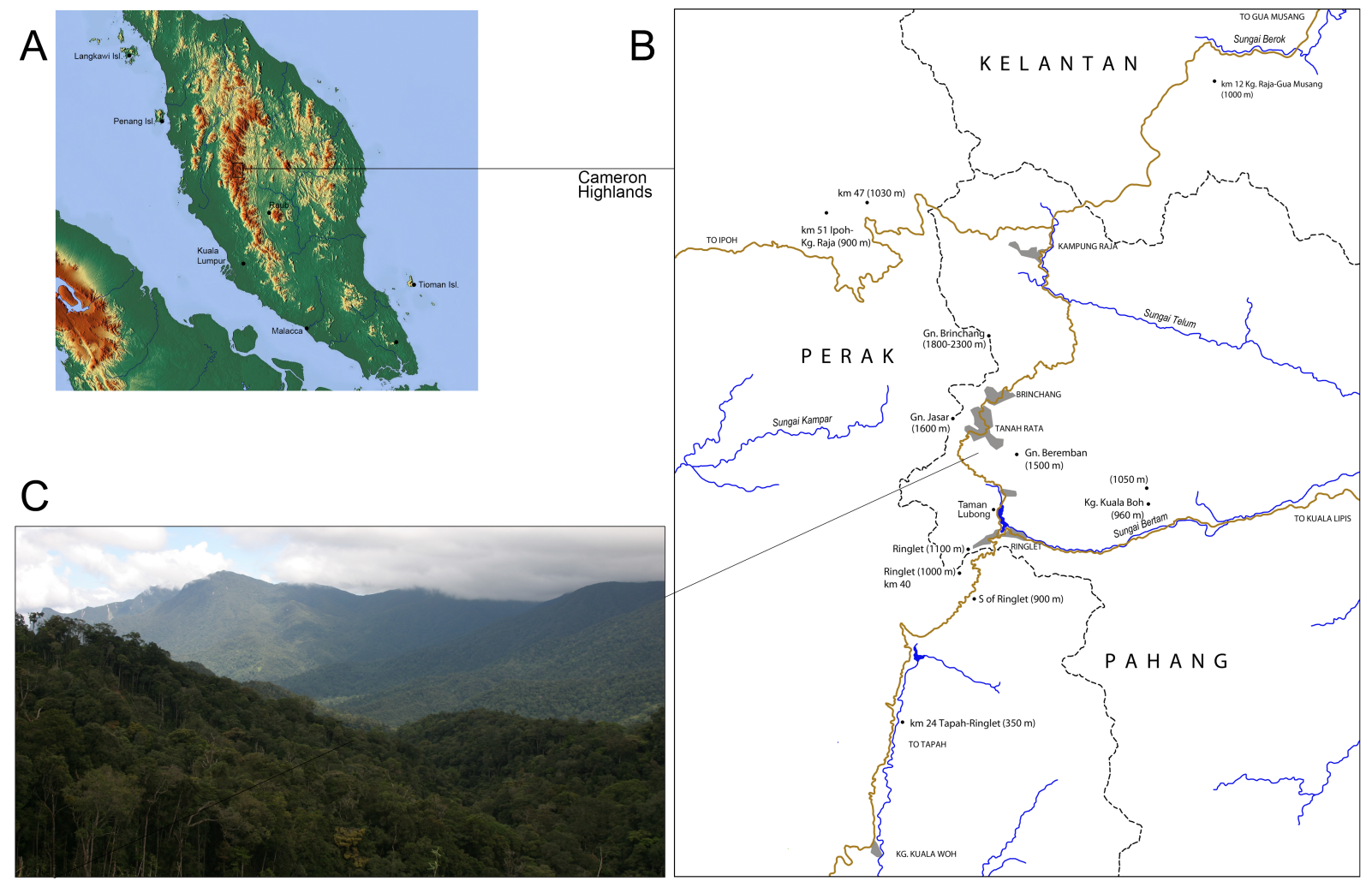

Fig. 1. The sampled localities in the Malay Peninsula. A. The localities in the Malay Peninsula. B. Detailed map of sampled localities in the Cameron Highlands region. C. Habitats in the Cameron Highlands mountain. 
Here, we present an alpha-taxonomic review of Cautires from the Malay Peninsula. The first species from Malaya were described by the end of the $19^{\text {th }}$ century (Waterhouse 1879; Kirsch 1875), but the fauna was only explored further in the 1920s and 30s when Pic (1925) and Kleine (1930a, b) reported several Cautires species in this region. Only a few of them were collected in the mountain forests at that time; most of the field work took place along the coast in the easily accessible lowlands and frequently visited places which were close to Malacca and Kuala Lumpur. Additionally, some species were described from the Penang and Langkawi islands. Due to the inaccessibility of the Malay inland until the late $1960 \mathrm{~s}$, the fauna of the mountain ranges remained poorly studied. Recently, an extensive collection of the Malay Cautires was assembled from the Cameron Highlands. The study deals with all species bearing more than three areolae in the pronotum, and this group of species corresponds with the original narrow delimitation of Cautires (Kleine 1933; Bocak 2002; but not Dudkova \& Bocak 2010 and Sklenarova et al. 2014). The Cautires obsoletus species group, which was earlier given the rank of a genus, i.e., Bulenides Waterhouse, 1879, was studied earlier (Jiruskova \& Bocak 2015) and all species of this species group are incorporated in the identification key. We delimit species using morphological diagnostic characters and we demonstrate the high species-level diversity of Cautires in the Malay mountain rainforests.

\section{Material and methods}

We had 159 specimens at our disposition from different localities in the Main Range of Peninsular Malaysia, mainly from the Cameron Highlands in the Titiwangsa Mountains (Fig. 1). Although the area is quite small, about $1000 \mathrm{~km}^{2}$, it covers various ecosystems from the lowland tropical forests close to Tapah (350 m a.s.1.), mid elevation forests in the area of Kampong Kuala Boh, Ringlet and along the roads from Cameron Highlands to Gua Musang, Kuala Lipis, and Ipoh (600-1000 m a.s.1.), and high mountain and cloud forests in the highest elevations of the Mt. Brinchang, Beremban and Jasar (1500$2000 \mathrm{~m}$ a.s.1.). The specimens were collected mostly by sweeping of the low forest stratum and beating of vegetation. The material was preserved in $96 \%$ alcohol and each specimen was given a voucher number consisting of two letters and four-digit number. All specimens designated by these voucher numbers are deposited in the collection of the Laboratory of Molecular Systematics, Palacký University, Olomouc, Czech Republic (LMBC). A piece of a metathoracic tissue of each specimen was deposited for future isolation of genomic DNA in the tissue collection of the same institution.

The study is based on adult males (Fig. 2) and, due to the absence of external morphological diagnostic characters and uniformity of female genitalia, we do not delimit any species when only females are available. Some females are included in the type series when they were collected simultaneously with the males and are phenotypically similar. As the identification of females is based on similarity to conspecific males, we do not provide detailed descriptions of females for each species. The differences in the structure of costae and ridges, the shape of the pronotum and colouration are variable in most species and do not provide reliable diagnostic characters. The density of transverse elytral costae depends on the body size of a specimen and colour patterns usually follow the most common co-mimetics in the locality and additionally the colouration partly depends on the altitude where the given population occurs. Generally, the mountain species are darker coloured or uniformly black (Fig. 79).

The tips of abdomen were placed in water to relax soft body parts for at least several hours and then transferred into hot $10 \%$ aqueous solution of potassium hydroxide for a short time depending on the level of sclerotization and the persistence of fat bodies and muscles. The phallus was removed from the abdominal sclerites, cleaned and photographed by a Canon EOS 700D camera mounted on an Olympus SZX-16 binocular microscope. A scale in the eyepiece was used to take the measurements of the individual body parts described below. 


\begin{abstract}
Abbreviations
$\mathrm{BL} \quad=$ body length measured from the tip of the clypeus to the tip of elytra

$\mathrm{PW}=$ pronotum width at the widest point, usually at the posterior angles

$\mathrm{PL}=$ pronotum length along the midline of the pronotum

HW = width at humeri at the point where elytra become parallel-sided

Ediam $=$ maximum eye diameter measured in the lateral view

Edist $=$ maximum eye distance measured in the frons

LP $\quad=$ length of the phallus
\end{abstract}

\title{
Deposition of material
}

The examined material mentioned in the study is deposited in the following institutions:

$\mathrm{BMNH}=$ Natural History Museum, London, UK

LMBC = Laboratory of Molecular Systematics, Palacký University Olomouc, Olomouc, Czech Republic (all specimens designated by the voucher numbers in this study)

MHNP = Museum national d'Histoire naturelle, Paris, France

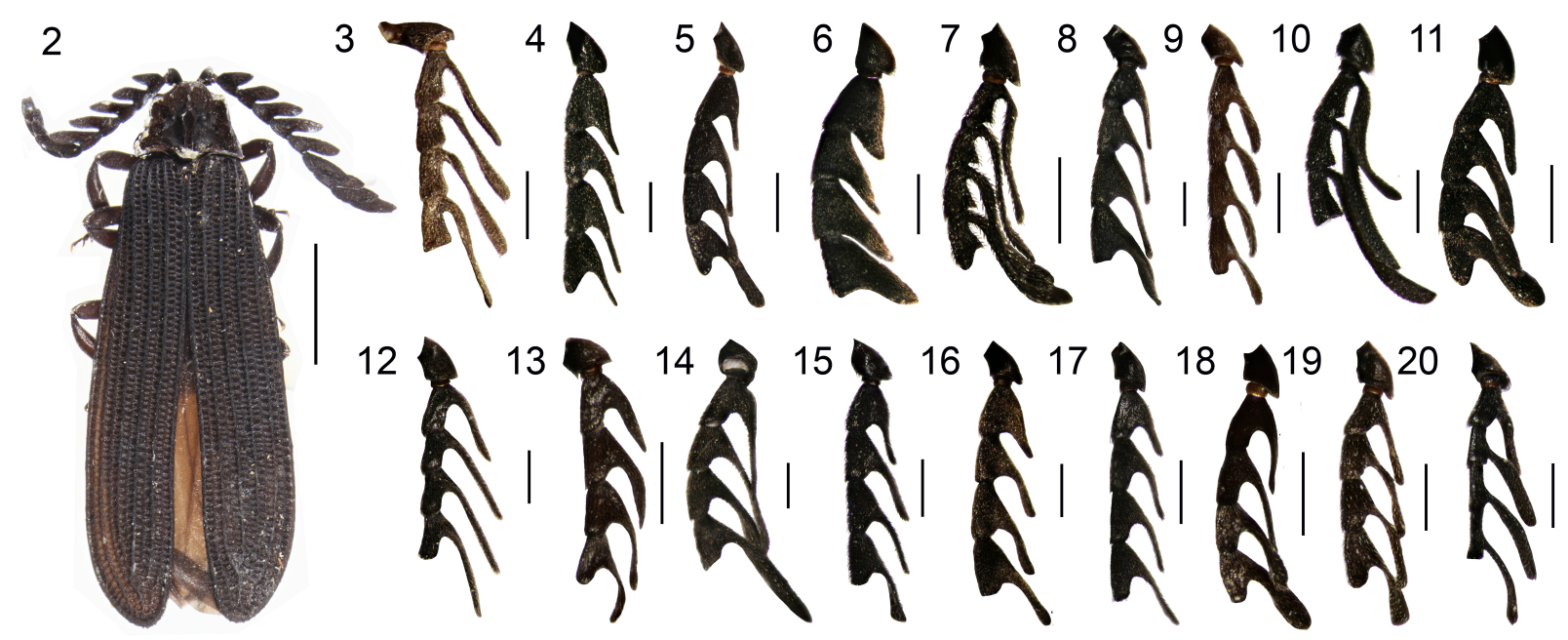

Figs 2-20. Cautires sp. 2. Habitus in dorsal view. 3-20. Male antennae. 3. C. alexae sp. nov. 4. C. andujari sp. nov. 5. C. arribasae sp. nov. 6. C. berembanensis sp. nov. 7. C. campestris sp. nov. 8. C. communis sp. nov. 9. C. griseus Kleine, 1930. 10. C. jasarensis sp. nov. 11. C. katarinae sp. nov. 12. C. kirstenae sp. nov. 13. C. kotatinggensis sp. nov. 14. C. linardi sp. nov. 15. C. maseki sp. nov. 16. C. pahangensis sp. nov. 17. C. nervosus Kleine, 1926. 18. C. renatae sp. nov. 19. C. reverandi Pic, 1925. 20. C. simillimus Kleine, 1926. Scale bars: Fig. $2=2.0 \mathrm{~mm}$; Figs $3-20=0.5 \mathrm{~mm}$. 


\title{
Results
}

\author{
Order Coleoptera Linnaeus, 1758 \\ Superfamily Elateroidea Leach, 1815 \\ Family Lycidae Laporte, 1836 \\ Subfamily Lycinae Laporte, 1836 \\ Tribe Metriorrhynchini Kleine, 1926 \\ Subtribe Cautirina Sklenarova, Kubecek \& Bocak, 2014 \\ Cautires Waterhouse, 1879 \\ Figs 6-20, 41-78
}

Cautires Waterhouse, 1879: 36. Type species: Lycus (gen. 22) excellens Waterhouse, 1878 by subsequent designation: Bourgeois 1891: 345.

Bulenides Waterhouse, 1879: 34. Type species: Lycus (gen. 21) obsoletus Waterhouse, 1878 by subsequent designation: Bourgeois 1891: 345.

Bulenides - Dudkova \& Bocak 2010: 34 .

\section{Diagnosis}

Cautires belongs to the subtribe Cautirina in close relationships to Xylobanus (Lycidae: Metriorrhynchini), from which it can be distinguished by continuous larval terga and a simple, usually slender phallus with a pair of sickle-shaped thorns in the internal sac (Sklenarova et al. 2014). Almost all Oriental Cautires have the male antennae flabellate (Figs 7-20), some species have very short lamellae and the antenna is acutely serrate (Fig. 6). The female antennae are always serrate. Each elytron bears four primary and five secondary longitudinal costae (Figs 41-58) and numerous transverse costae connecting them. Cautires species have the lanceolate phallus with membranous internal sac bearing two sickle-shaped thorns at its base (Figs 59-78).

\section{Remark}

The revised concept of Cautires merged the genera Bulenides Waterhouse, 1879 and Cautires Waterhouse, 1879 (Dudkova \& Bocak 2010). Later, the terminal position of Bulenides within the Cautires clade was confirmed by subsequent molecular phylogenetic study by Sklenarova et al. (2014). The latter study also redefined the limits of Xylobanus Waterhouse, 1879, which was originally defined by the absence of secondary costae. Some Xylobanus have elytral costae similar to those of Cautires and adults of these species can be identified using the shape of male genitalia. The species group of $C$. obsoletus corresponds with the limits of Bulenides and these species differ in absence of lateral ridges in the pronotum.

\section{Key to males of Cautires from the Malay Peninsula}

1. Pronotum with three areolae, i.e., only median longitudinal keel present in pronotum with

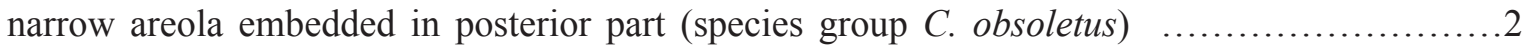

- Pronotum with more than three areolae, i.e. postero- and antero-lateral ridges developed in pronotum, either of them can be vestigial, but always at least some part remains apparent (Cautires sensu Kleine, 1933) ....................................................................... 11

2. Pronotum wide, flat, with very slender median areola in basal half of median keel ..................3

- Pronotum narrow frontally, without wide lateral areolae, median areola slightly wider, usually longer than frontal keel 
3. Only basal part of elytral costae brightly red coloured, phallus slender

C. pauperulus (Bourgeois, 1883)

- Basal two thirds of elytra light brown, phallus widened apically ...C. malayensis (Kleine, 1930)

4. Whole elytra uniformly black

- At least humeral part of elytral costae with bright red or orange pubescence or variable humeral part of elytra brightly coloured

5. Phallus parallel-sided, without any extended part

C. parallelus Jiruskova \& Bocak, 2015

- Phallus widest in apical fourth

C. imitator (Kleine, 1930)

6. The maximum eye diameter 1.2-1.3 larger than interocular distance

- The maximum eye diameter small, 0.6-0.9 times their interocular distance

7. Phallus very slender, widest in middle part, apical two-fifths parallel-sided, lamella of antennomere 5 about twice longer than its stem

C. coccineus (Kleine, 1930)

- Phallus widest in apical third, apical part gradually narrower to apex

8. Lamella of antennomere 5 about twice longer than its stem, apex of phallus rounded

C. paraimitator Jiruskova \& Bocak, 2015

- Lamella of antennomere 5 about 1.5 times longer than its stem, apex of phallus pointed

C. tanahratensis Jiruskova \& Bocak, 2015

9. Antennomere 5 with lamella about twice longer than its stem, elytral costae with bright pubescence in whole length

C. nebulosus (Kleine, 1930b)

- Antennomere 5 with lamella at most 1.5 times longer than its stem, elytral costae with bright pubescence at most in humeral half ....

10. Phallus widest in middle part

C. tapahensis Jiruskova \& Bocak, 2015

- Phallus widest in apical third C. indus (Kirsch, 1875)

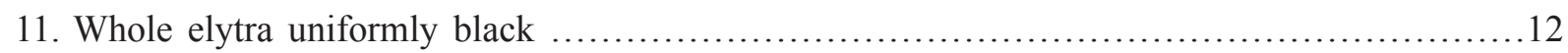

- At least humeral part of elytral costae with bright red or orange pubescence or variable humeral part of elytra brightly coloured

12. The maximum eye diameter 1.1 times larger than interocular distance C. linardi sp. nov.

- The maximum eye diameter 0.4-0.95 times interocular distance

13. Male antennomeres 3 and 4 with slender basal part of their lamellae, lamella attached to basal part of antennomere (Figs 10, 12)

- Male antennomere 3 and 4 with basally robust lamella, lamella attached to middle or apical part of antennomere (Figs 4, 6, 8, 15, 17, 20) .

14. Antennomere 3 with lamella about 1.5 times longer than stem of antennomere, phallus relatively robust, pointed at apex, 6.7 times longer than wide at widest point (Fig. 78) ......C. tenebricus (Kleine, 1930)

- Antennomere 3 with lamella twice or more longer than stem of antennomere (Figs 10,12), if phallus pointed at apex then very slender, nine times longer than wide at widest point (Fig. 68) .........15

15. The apex of phallus widely rounded, antennomere 3 with its lamella three times longer than stem of antennomere (Fig. 10) .......................................... jasarensis sp. nov.

- The apex of phallus acutely pointed, antennomere 3 with its lamella about twice longer than stem of antennomere (Fig. 12)

C. kirstenae sp. nov. 
16. Phallus parallel-sided and very slender, at least nine times longer than width in widest part (Figs 62,

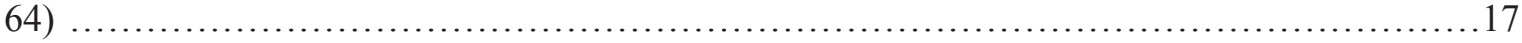

- Phallus relatively robust, often widened in some part (Figs $60,71,73,76) \ldots \ldots \ldots \ldots \ldots \ldots \ldots \ldots$

17. Phallus extremely slender, almost parallel-sided in apical part, antennomere 3 triangular, without slender lamella (Fig. 6) ...

C. berembanensis sp. nov.

- Phallus slender, gradually narrowed in apical part (Fig. 64), antennomere 3 withlamella about twice longer than stem of antennomere (Fig. 8)

C. communis sp. nov.

18. Maximum eye diameter about 0.9 times interocular distance 19

- Maximum eye diameter 0.5-0.8 times interocular distance

19. Basal part of phallus considerably slenderer than apical half (Fig. 60) ........ . andujari sp. nov.

- Basal part of phallus only slightly slenderer than apical half (Fig. 76) ...C. simillimus Kleine, 1926

20. Maximum diameter of eyes about $0.7-0.8$ times larger than interocular distance, the phallus very wide in apical half (Fig. 71)

C. maseki sp. nov.

- Maximum diameter of eyes about 0.5-0.6 times larger than interocular distance, the phallus moderately wide in apical half (Fig. 73) .... C. nervosus Kleine, 1926

21. Maximum eye diameter equal or larger than interocular distance

- Maximum eye diameter 0.7 times interocular distance

C. alexae sp. nov.

22. Maximum diameter of eyes equal or up to 1.4 times interocular distance 23

- Maximum diameter of eyes extremely large, more than 1.6 times interocular distance, phallus moderately robust, parallel-sided (Fig. 65).

C. griseus Kleine, 1930

23. Pronotum as wide as long at midline, phallus slender, gradually narrower from widest part at two fifths of its length to base and apex (Fig. 77) C. selangorensis Kleine, 1930

- Pronotum at least 1.1 times wider than long at midline, in most species 1.3-1.4 times wider,

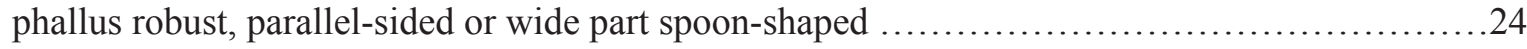

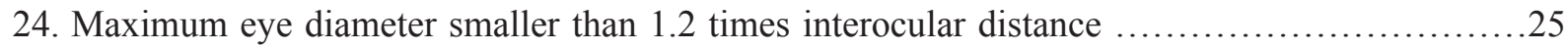

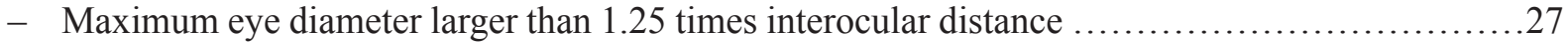

25. Male antennomeres 3 and 4 with slender basal part of lamella, lamella attached to basal part of antennomere (Fig. 7)

C. campestris sp. nov.

- Male antennomeres 3 and 4 with basally robust lamella, lamella short, about 1.5 times length of

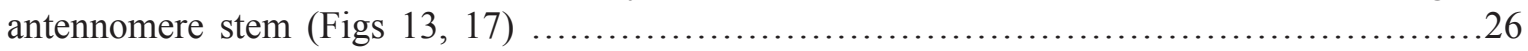

26. Parallel-sided part of phallus occupies lightly more than basal half of its length

C. kotatinggensis sp. nov.

- Parallel-sided part of phallus occupies about one basal third of its length, phallus slender

C. pahangensis sp. nov.

27. Lamella of antennomere 3 shorter than 1.3 times stem of antennomere, phallus slender in basal two thirds, widened apical part almost twice wider than basal part of phallus, widest close to mid of phallic length .............................................. arribasae sp. nov.

- Lamella of antennomere 3 at least 1.5 longer than stem of antennomere, phallus slender in basal

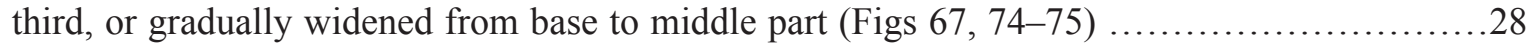


28. Phallus gradually widened from base to middle part, with obtuse apex (Fig. 67) ...C. katarinae sp. nov.

- Phallus almost parallel sided at least in basal quarter of its length, with slender apex (Figs 74-75) ...29

29. Phallus slightly constricted in middle of widest part

C. renatae sp. nov.

- Phallus widest in middle of widened part (Fig. 75) C. reverandi Pic, 1925

Cautires alexae sp. nov. urn:Isid:zoobank.org:act:9FAD9D3C-3443-41F8-83F6-D1F0860DAA4D

Figs 3, 21, 41, 59

\section{Diagnosis}

Cautires alexae sp. nov. is one of the species with a reddish humeral part of the elytra (Fig. 41), the pronotum with black pubescence (Fig. 21) and the medium size of the male eyes. It differs from the similar species in the widened apical third of the phallus and its obtuse apex (Fig. 59).

\section{Etymology}

The specific epithet alexae is a matronym in honour of Alex Crampton-Platt, a colleague from the Natural History Museum in London.

\section{Type material}

\section{Holotype}

MALAYSIA: §ૈ, Perak, Banjaran Titiwangsa, Ringlet, 900 m, 29 Mar.-15 Apr. 2004 (Voucher number VK0433).

\section{Paratype}

MALAYSIA: $\hat{\jmath}$, same locality data (VK0432).

\section{Measurements}

BL 7.2 mm, PL 1.1 mm, PW 1.6 mm, HW 0.95 mm, Edist 0.58 mm, Ediam 0.42 mm, LP 0.92 mm.

\section{Description of the male}

Body slender, black, only basal half of primary and secondary elytral costae with reddish pubescence (Fig. 41). Head small, eyes large, hemispherically prominent, eye diameter 0.72 times interocular distance. Antennae flabellate (Fig. 3). Pronotum with 5 areolae, posterior costae sharp in lateral parts and obtuse in middle part of pronotum, median areola complete, median areola attached directly to basal margin; anterior angles obtuse, lateral margins slightly concave, elevated, posterior angles prominent, pronotum with black pubescence (Fig. 21). Elytra parallel-sided, secondary costae well developed in humeral part and week apically, transverse costae dense (Fig. 41). Phallus wide in apical third, obtuse at apex (Fig. 59).

\section{Distribution}

Peninsular Malaysia: Perak. Cautires alexae sp. nov. is known only from the type locality. 


\section{Cautires andujari sp. nov. \\ urn:1sid:zoobank.org:act:2C5A1461-1A75-43F3-856C-E3C5437A0264}

Figs 4, 22, 39, 42, 60

\section{Diagnosis}

Cautires andujari sp. nov. belongs to a group of mountain species with a uniformly black upper side of the body. The species is similar in general appearance to Cautires maseki sp. nov., but differs in the length of the male antennal lamellae (Figs 4, 15) and the shape of the phallus (Figs 60, 71).

\section{Etymology}

The specific epithet is honour of Carmelo Andújar Fernandéz, a specialist in the ecology of ground beetles.
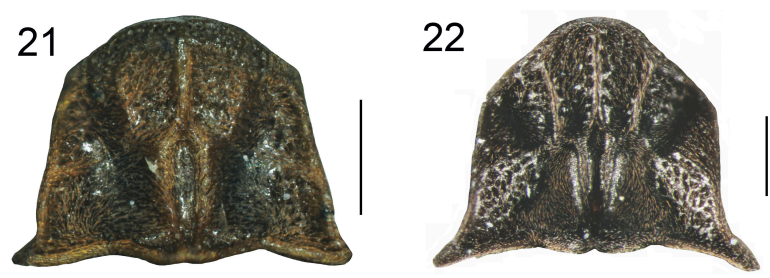

23
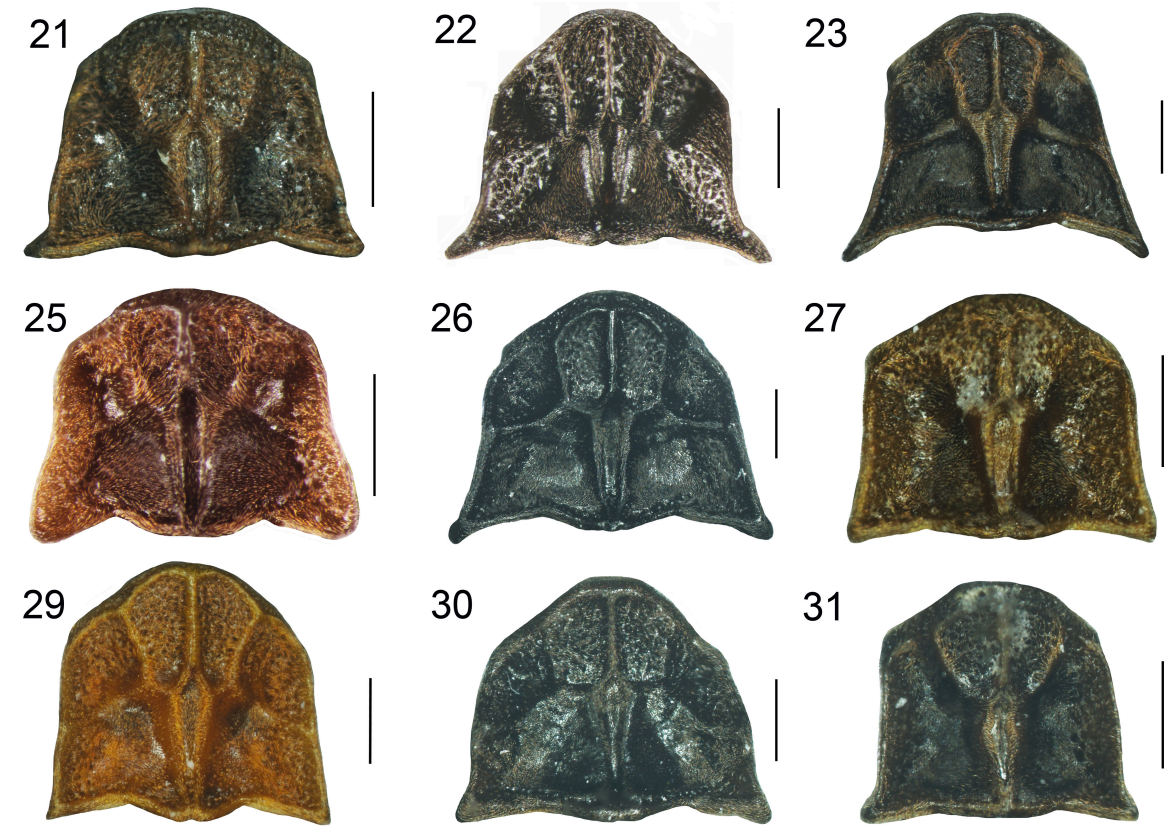

33
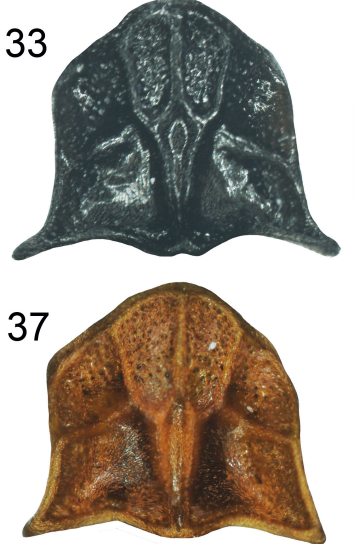

30
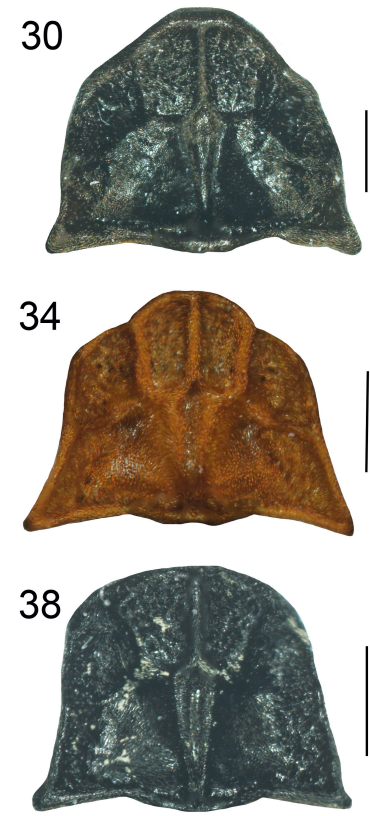

27

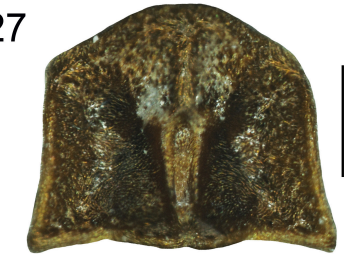

31

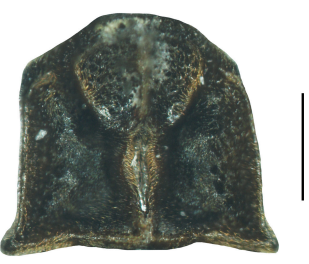

35

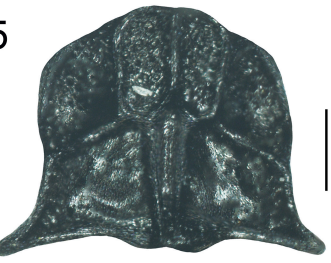

39

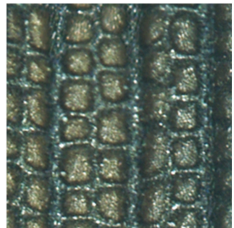

24

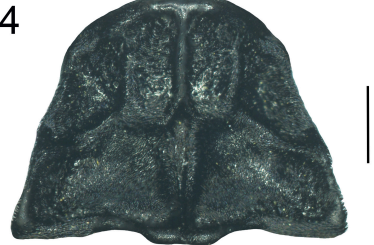

28

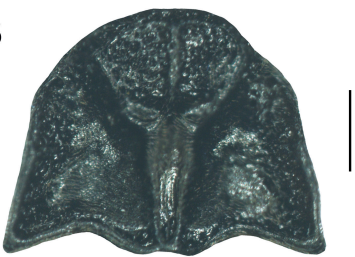

32

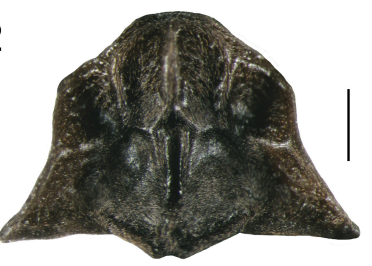

36

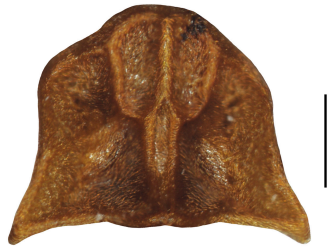

40

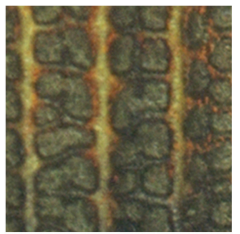

Figs 21-38. Male pronotum. 21. Cautires alexae sp. nov. 22. C. andujari sp. nov. 23. C. arribasae sp. nov. 24. C. berembanensis sp. nov. 25. C. campestris sp. nov. 26. C. communis sp. nov. 27. C. griseus Kleine, 1930. 28. C. jasarensis sp. nov. 29. C. katarinae sp. nov. 30. C. kirstenae sp. nov. 31. C. kotatinggensis sp. nov. 32. C. linardi sp. nov. 33. C. maseki sp. nov. 34. C. pahangensis sp. nov. 35. C. nervosus Kleine, 1926. 36. C. renatae sp. nov. 37. C. reverandi Pic, 1925. 38. C. simillimus Kleine, 1926. - 39-40. Male elytra costae, detail: 39. C. andujari sp. nov. 40. C. campestris sp. nov. Scale bars $=0.5 \mathrm{~mm}$. 


\section{Type material}

\section{Holotype}

MALAYSIA: đ̊, Pahang, Gn. Brinchang, 1800 m, 4³0'34" N, 101²3'09" E, 12-16 Apr. 2013 (AJ0082).

\section{Paratypes}

MALAYSIA: 1 , same locality data (AJ0083); 1 ภ, 3 우, Pahang, Tanah Rata, 1500-1800 m, 2-26 Feb. 2004 (VK0272, VK0312, VK0322, VK0519); 2 ふ઼ ô, 1 오, Pahang, Tanah Rata, 1600 m, Gn. Jasar, 3-9 Feb. 2005, Bolm leg. (VK0251, VK0426, VK0564).

\section{Measurements}

BL 10.7 mm, PL 1.5 mm, PW 2.25 mm, HW 1.2 mm, Edist 0.61 mm, Ediam 0.58 mm, LP 1.8 mm.
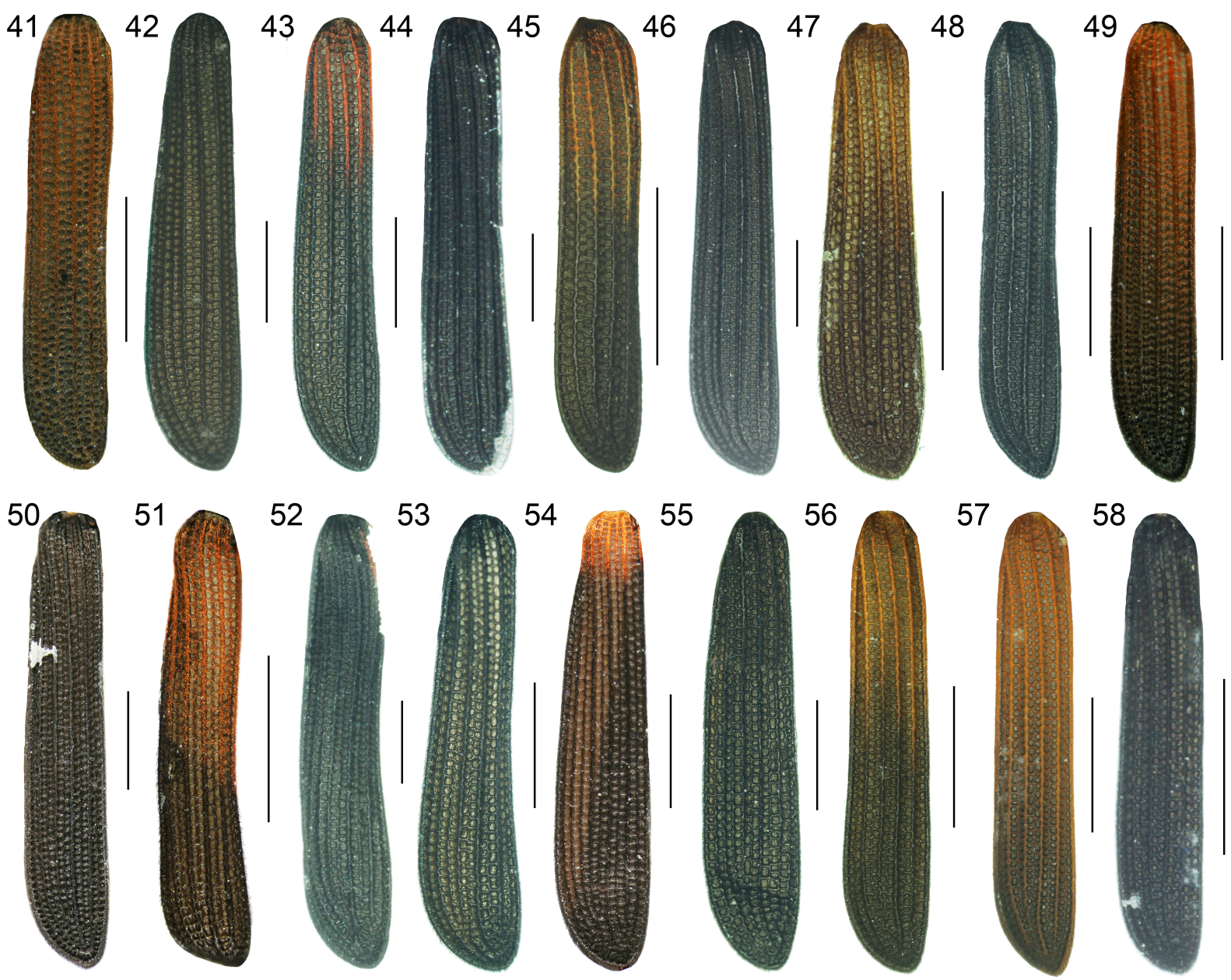

Figs 41-58. Male elytra. 41. Cautires alexae sp. nov. 42. C. andujari sp. nov. 43. C. arribasae sp. nov. 44. C. berembanensis sp. nov. 45. C. campestris sp. nov. 46. C. communis sp. nov. 47. C. griseus Kleine, 1930. 48. C. jasarensis sp. nov. 49. C. katarinae sp. nov. 50. C. kirstenae sp. nov. 51. C. kotatinggensis sp. nov. 52. C. linardi sp. nov. 53. C. maseki sp. nov. 54. C. pahangensis sp. nov. 55. C. nervosus Kleine, 1926. 56. C. renatae sp. nov. 57. C. reverandi Pic, 1925. 58. C. simillimus Kleine, 1926. Scale bars = $1.0 \mathrm{~mm}$. 


\section{Description of the male}

Body uniformly black (Figs 22, 42). Head small, eyes hemispherically prominent, eye diameter 0.95 times interocular distance. Antennae flabellate with short, slender lamella of antennomere 3 (Fig. 4). Pronotum with 7 areolae, but postero-lateral costae inconspicuous, median areola complete, sharp ridges, median areola attached directly to basal margin; anterior angles obtuse, lateral margins concave, strongly elevated, posterior angles acutely prominent (Fig. 22). Elytra slightly widened apically, primary and secondary costae well developed (Fig. 39), transverse costae dense (Fig. 42). Phallus robust, slender basally, apical part obtuse (Fig. 60).

\section{Distribution}

Peninsular Malaysia: Pahang. Cautires andujari sp. nov. is known only form the highest elevations of the Cameron Highlands.

\section{Cautires arribasae sp. nov. \\ urn:Isid:zoobank.org:act:F77DC4A6-0363-4131-A8AA-B9334D4198CE}

Figs 5, 23, 43, 61

\section{Diagnosis}

Cautires arribasae sp. nov. is one of the species with a brightly coloured humeral part of elytra and black pronotum. The species resembles $C$. alexae sp. nov. and $C$. kotatinggensis sp. nov. in general appearance and differs in the large eyes, the shape of the pronotum (Figs 21, 23, 31), and phallus (Figs 59, 61, 69).

\section{Etymology}

The specific epithet is proposed in honour of Paula Arribas, a colleague studying beetle soil communities.

\section{Type material}

\section{Holotype}

MALAYSIA: đ̊, Pahang, Gn. Beremban, 1480 m, 4²7'51" N, 101²3'26" E, 6-28 Apr. 2013 (AJ0079).

\section{Paratypes}

MALAYSIA: 3 $\widehat{\partial}, 3$ 우, same locality data (AJ0058, AJ0059, AJ0062, AJ0064, AJ0066, AJ0078).

\section{Measurements}

BL 9.8 mm, PL 1.5 mm, PW 2.05 mm, HW 1.15 mm, Edist 0.5 mm, Ediam 0.68 mm, LP 1.67 mm.

\section{Description of the male}

Body slender, black, only basal fourth of primary and fifth of secondary elytral costae with reddish pubescence (Fig. 43). Head small, hemispherically prominent, eyes large, eye diameter 1.36 times interocular distance. Antennae flabellate (Fig. 5). Pronotum with 7 areolae, median areola complete, marked by sharp ridges, attached directly to basal margin of pronotum; anterior angles obtuse, lateral margins slightly concave, lateral part of pronotum strongly elevated, posterior angles acutely prominent, pronotal margins and costae covered with brown, dense pubescence (Fig. 23). Elytra parallel-sided, secondary costae well developed, transverse costae dense (Fig. 43). Phallus robust, slender in basal part, its apex obtuse (Fig. 61).

\section{Distribution}

Peninsular Malaysia: Pahang. Cautires arribasae sp. nov. is known only from the mountain forests in the Cameron Highlands. 


\section{Cautires berembanensis sp. nov. urn:Isid:zoobank.org:act:35C6DBC0-52EF-49A9-BDEF-9E8C4EADEE40}

Figs 6, 24, 44, 62

\section{Diagnosis}

Cautires berembanensis sp. nov. belongs to a group of the species with the black body and very small eyes. The species is characteristic in the very wide, flat male antennomeres 3-10 (Fig. 6), which is unknown in other Malay species and in the extremely slender phallus (Fig. 62).

\section{Etymology}

The specific epithet refers to the type locality of the holotype.

\section{Type material}

\section{Holotype}

MALAYSIA: ${ }^{\Uparrow}$, Pahang, Gn. Beremban, 1480 m, 4²7'51" N, 101²3'26" E, 6-28 Apr. 2013 (AJ0092).

Paratypes

MALAYSIA: 1 ㄱ, 2 우, Pahang, Tanah Rata, 1500-1800 m, 2-26 Feb. 2004 (VK0254, VK0275, VK0278).

\section{Measurements}

BL $12.1 \mathrm{~mm}$, PL $1.65 \mathrm{~mm}$, PW $2.1 \mathrm{~mm}$, HW $1.5 \mathrm{~mm}$, Edist $0.77 \mathrm{~mm}$, Ediam $0.33 \mathrm{~mm}$, LP $1.21 \mathrm{~mm}$.

\section{Description of the male}

Body uniformly black (Fig. 44). Head small, eyes hemispherically prominent, but small, eye diameter 0.42 times interocular distance. Antennae acutely serrate (Fig. 6). Pronotum with 7 areolae, fronto-lateral costae vestigial in proximity to pronotal margin, median areola complete, attached basally directly to pronotal margin; anterior angles obtuse, lateral margins only slightly elevated, straight in whole length (Fig. 24). Elytra parallel-sided, secondary costae well developed, transverse costae dense (Fig. 44). Phallus extremely slender, stick-shaped, only very slightly wider in apical fourth, slightly pointed at apex (Fig. 62).

\section{Distribution}

Peninsular Malaysia: Pahang.

Cautires campestris sp. nov.

urn:1sid:zoobank.org:act:6F1955CA-3699-4BBC-8673-5DC0D1718774

Figs 7, 25, 40, 45, 63

\section{Diagnosis}

Cautires campestris sp. nov. is one of the species with a brightly coloured humeral part of the elytra, reddish pubescence on the disc of the pronotum and large eyes. This species has very long, slender antennal lamellae (Fig. 7), which resemble very closely those of the black coloured species $C$. jasarensis sp. nov. Additionally, C. campestris sp. nov. differs from other species in the robust phallus and the pronotum with vestigial postero-lateral ridges.

\section{Etymology}

The specific epithet refers to the lowland distribution of the species. 
Type material

Holotype

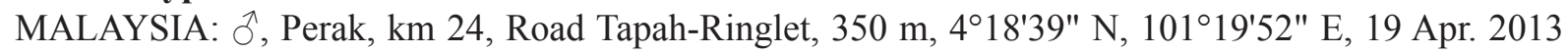
(AJ0039).
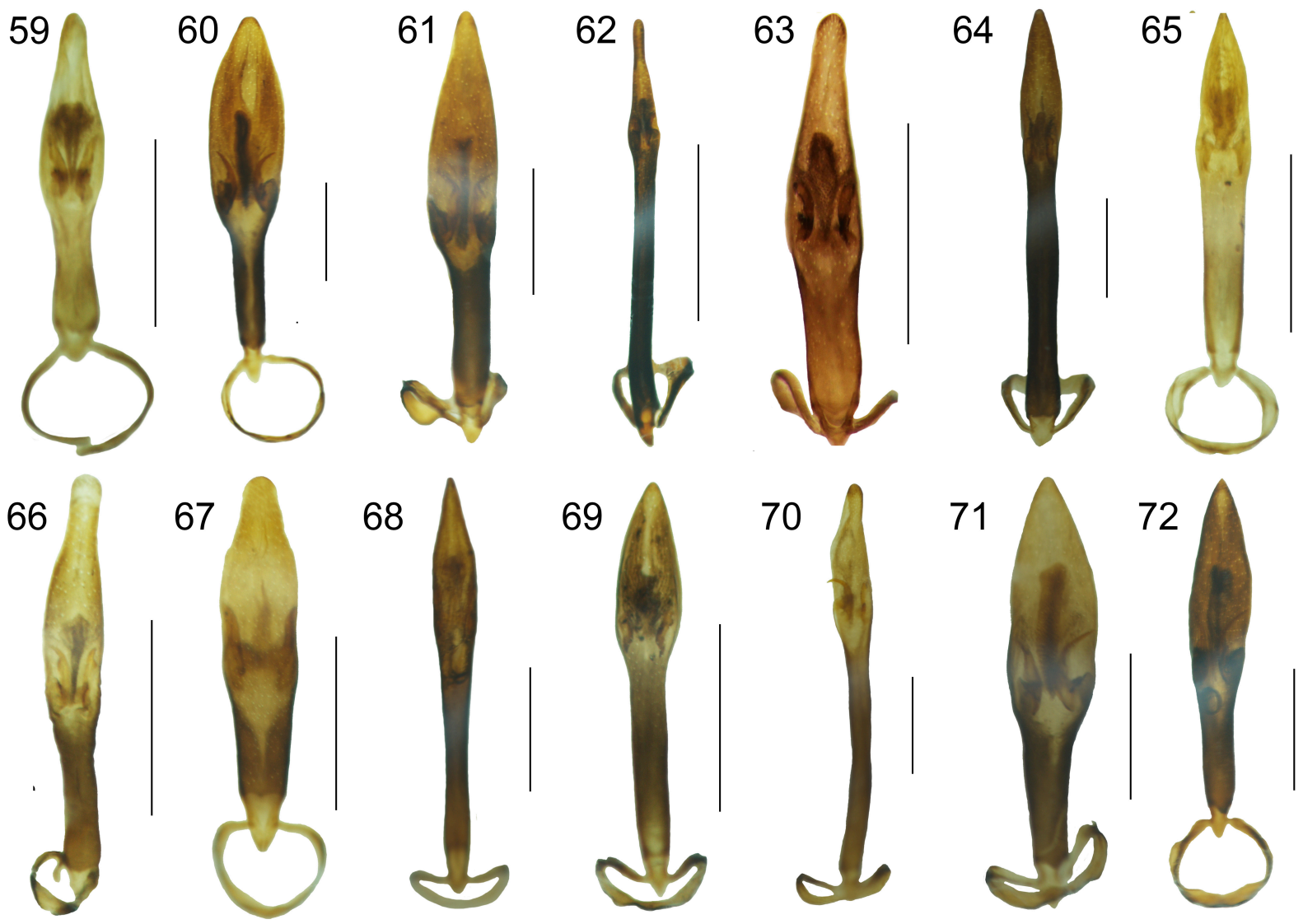

72
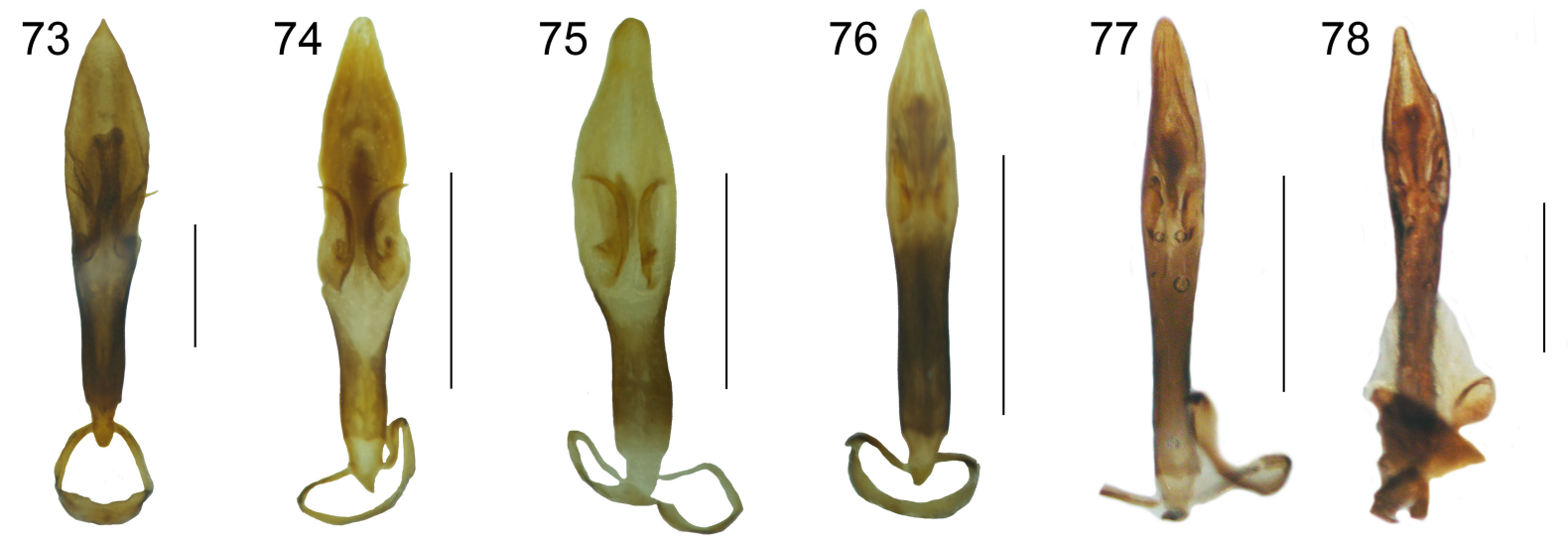

Figs 59-78. Phallus. 59. Cautires alexae sp. nov. 60. C. andujari sp. nov. 61. C. arribasae sp. nov. 62. C. berembanensis sp. nov. 63. C. campestris sp. nov. 64. C. communis sp. nov. 65. C. griseus Kleine, 1930. 66. C. jasarensis sp. nov. 67. C. katarinae sp. nov. 68. C. kirstenae sp. nov. 69. C. kotatinggensis sp. nov. 70. C. linardi sp. nov. 71. C. maseki sp. nov. 72. C. pahangensis sp. nov. 73. C. nervosus Kleine, 1926. 74. C. renatae sp. nov. 75. C. reverandi Pic, 1925. 76. C. simillimus Kleine, 1926. 77. C. selangorensis Kleine, 1930. 78. C. tenebricus Kleine, 1926. Scale bar $=0.5 \mathrm{~mm}$. 
Paratypes

MALAYSIA: 2 우, same locality data (AJ0040-AJ0041); 2 우, Kelantan, km 12, Road Kg. Raja-Gua Musang, 780 m, 4³8'15" N, 101³0'11" E, 20 Apr. 2013 (AJ0032, AJ0096).

\section{Measurements}

BL 6.5 mm, PL 1.0 mm, PW 1.55 mm, HW 0.9 mm, Edist 0.5 mm, Ediam 0.57 mm, LP 1.0 mm.

\section{Description of the male}

Body slender, black, only basal third of primary and secondary elytral costae with reddish pubescence (Fig. 45). Head small, eyes hemispherically prominent, moderately large, eye diameter 1.14 times interocular distance. Antennae flabellate, lamellae very long, slender, attached to base of antennomere (Fig. 7). Pronotum flat, with 7 areolae, median areola well-developed, ridges sharp, median areola attached directly to basal margin of pronotum; anterior pronotal angles obtuse, lateral margins concave, lateral part of pronotum strongly elevated, posterior angles only weakly prominent, rounded apically, pronotum with orange pubescence on edges (Fig. 25). Elytra parallel-sided, secondary costae week (Fig. 40), transverse costae dense (Fig. 45). Phallus moderately robust, widest in the middle part, obtuse at apex (Fig. 63).

\section{Distribution}

Peninsular Malaysia: Perak, Kelantan. The species is widely distributed in low elevations of the Cameron Highlands region.

\section{Cautires communis sp. nov. urn:lsid:zoobank.org:act:B24A79EF-21BA-450A-BB56-D19D7F613EED}

Figs 8, 26, 46, 64

\section{Diagnosis}

Cautires communis sp. nov. belongs to the group of species with a black body and large male eyes. The species resembles $C$. kirstenae sp. nov. in the relatively slender phallus (Figs 64, 68), but these species differs in the relative length of antennal lamellae (Figs 8, 12). The antennal lamellae of $C$. communis sp. nov. are wide at the base and slightly short.

\section{Etymology}

The specific epithet refers to the abundance of the species. Altogether 52 specimens were identified in the available material and it makes $C$. communis sp. nov. the most common species in the Cameron Highlands.

\section{Type material}

\section{Holotype}

MALAYSIA: §̊, Pahang, Gn. Beremban, 1480 m, 4²7'51" N, 101²3'26"E, 6-28 Apr. 2013 (AJ0091).

\section{Paratypes}

MALAYSIA: 1 ô, 4 q , Pahang, Tanah Rata, 1600 m, Gn. Jasar, 3-9 Feb. 2005 (VK0563, VK0568, VK0619, VK0622, VK00623); 1 o, 1 q, Pahang, Tanah Rata, 24-31 Jan. 2003 (VK0268, VK0450); 2 우, Pahang, Tanah Rata, 1600 m, 3-20 Feb. 2005 (VK0361, VK0418, VK0421, VK0526, VK0572); 1 ㅇ, Pahang, Tanah Rata, 1400-1650 m, 4-11 Apr. 2005 (VK0310); 2 우우, Pahang, Brinchang, Gn.

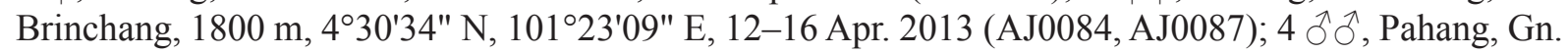
Beremban, 1480 m, 4²7'51" N 101²3'26" E, 6-28 Apr. 2013 (AJ0013, AJ0061, AJ0068, AJ0093); 1 ô, 1 ㅇ, Pahang, Gn Jasar, N slope, 1550 m, 4²8'56" N, 101²1'55" E, 11 Apr. 2013 (AJ0004, AJ0006); 
23 ภิô, 11 우, Pahang, Tanah Rata, 1500-1800 m, 2-26 Feb. 2004 (VK0242, VK0244, VK0245, VK0246, VK0255, VK0260, VK0261, VK0262, VK0263, VK0264, VK02605, VK0267, VK0271, VK0274, VK0276, VK0277, VK0278, VK0279, VK0311, VK0313, VK00314, VK0316, VK0317, VK0321, VK0323, VK0324, VK0325, VK0512, VK0513, VK0514, VK0515, VK0520, VK0521, VK0523, VK0524).

\section{Measurements}

BL 12.2 mm, PL 1.75 mm, PW 2.35 mm, HW 1.4 mm, Edist 0.75 mm, Ediam 0.55 mm, LP $2.2 \mathrm{~mm}$.

\section{Description of the male}

Body uniformly black (Fig. 46). Head small, eyes hemispherically prominent, eye diameter 0.73 times interocular distance. Antennae flabellate with moderately long lamellae widely attached to stem of antennomere (Fig. 8). Pronotum with 7 well developed areolae, median areola complete, marked by sharp ridges, attached directly to basal margin of pronotum; anterior angles obtuse, lateral margins slightly concave, strongly elevated, posterior angles acutely prominent (Fig. 26). Elytra almost parallelsided, only very slightly widened posteriorly, primary and secondary costae well developed, transverse costae dense (Fig. 46). Phallus slender, stick-shaped, only slightly widened in apical part, obtusely pointed at apex (Fig. 64).

\section{Distribution}

Peninsular Malaysia: Pahang. Cautires communis sp. nov. was collected only in the highest part of the Cameron Highlands and does not occur on the northern slopes in lower elevations.

\section{Cautires griseus Kleine, 1930}

Figs 9, 27, 47, 65

Cautires griseus Kleine, 1930a: 96.

\section{Diagnosis}

Cautires griseus belongs to the group of species with a bright humeral part of the elytra (Fig. 47) and brown pubescence in the disc of the pronotum (Fig. 27). It differs from similarly coloured species in the length of antennal lamellae (Fig. 9) and in the relatively robust, shorter, parallel-sided phallus (Fig. 65).

\section{Type material}

\section{Holotype}

MALAYSIA: $\curvearrowright$, Perak, Doherty (BMNH).

\section{Additional material examined}

MALAYSIA: 1 ô, Pahang, Tanah Rata, 1600 m, Cameron Highlands, 3-20 Feb. 2005 (VK0575); 1 + Kelantan, Road Ipoh-Kg. Raja, 35 km E of Ipoh, 980 m, 8 Feb. 2005 (VK0308).

\section{Measurements}

BL 6.7 mm, PL 1.10 mm, PW 1.15 mm, HW 1.0 mm, Edist 0.34 mm, Ediam 0.61 mm, LP $1.07 \mathrm{~mm}$.

\section{Distribution}

Peninsular Malaysia: Perak, Pahang, Kelantan. 


\section{Cautires jasarensis sp. nov. urn:1sid:zoobank.org:act:7E53ED05-01B4-40F4-869B-AF04B3B9CAD9}

Figs 10, 28, 48, 66

\section{Diagnosis}

Cautires jasarensis sp. nov. is similar to $C$. kirstenae sp. nov. Both species share the uniformly black body, pronotum and elytra, the relatively small, hemispherically prominent eyes and the long antennal lamellae (Figs 28, 30, 48, 50). C. kirstenae sp. nov. and the similarly coloured C. communis sp. nov. have a slender phallus pointed at the apex (Figs 64,68), but the phallus of $C$. jasarensis sp. nov. is much wider in its apical third and its apical part is parallel-sided. The phallic apex of $C$. jasarensis sp. nov. is widely rounded in contrast with other species in the region (Fig. 66).

\section{Etymology}

The specific epithet refers to the Mt. Jasar, the locality where a part of the type series was collected.

\section{Type material}

\section{Holotype}

MALAYSIA: đ̊, Pahang, Gn. Beremban, 1480 m, 4²7'51" N, 101²3'26"E, 6-28 Apr. 2013 (AJ0067).

\section{Paratypes}

MALAYSIA: 1 กै, 1 q, Pahang, Gn. Beremban, 1480 m, 4²7'51" N, 101²3'26" E, 6-28 Apr. 2013 (AJ0070); 1 J, 2 우, Pahang, Tanah Rata, Gn. Jasar, 1600 m, 3-20 Feb. 2005 (VK0425, VK0362,

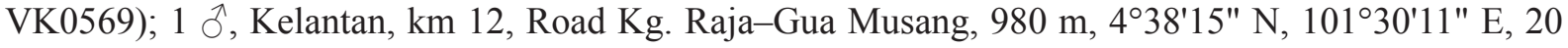
Apr. 2013 (AJ0034); 2 우, Pahang, Tanah Rata, Gn. Jasar, 1600 m, 3 Jan. 2005 (VK0252, VK0253); 1 §ै, Pahang, Tanah Rata, 1600 m, Gn. Jasar, 3-9 Feb. 2005, Bolm leg. (VK0565); 1 中, Pahang, km 51, Road Ipoh - Kg. Raja, 1100 m, 4 Feb. 2005 (VK0437).

\section{Measurements}

BL 8.7 mm, PL 1.5 mm, PW 1.7 mm, HW $1.1 \mathrm{~mm}$, Edist $0.68 \mathrm{~mm}$, Ediam $0.50 \mathrm{~mm}$, LP $1.08 \mathrm{~mm}$.

\section{Description of the male}

Body black (Fig. 48). Head small, eyes hemispherically prominent, relatively small, eye diameter 0.73 times interocular distance. Antennae flabellate, lamellae very slender, including their bases, attached to basal part of antennomeres (Fig. 10). Pronotum with 7 well developed areolae, posterior costae obtuse, inconspicuous, median areola complete, marked with complete ridges, attached directly to basal margin; anterior angles obtuse, lateral margins strongly elevated, very slightly concave in anterior part of pronotum, straight and divergent in posterior part (Fig. 28), posterior angles sharp, but not acutely projected. Elytra parallel-sided, primary and secondary costae well developed, transverse costae dense (Fig. 48). Phallus moderately slender, widest in apical third, obtuse at apex (Fig. 66).

\section{Distribution}

Peninsular Malaysia: Pahang, Kelantan. This species is widely distributed in the Cameron Highlands. 


\section{Cautires katarinae sp. nov. urn:Isid:zoobank.org:act:98428C4C-91DD-4AB8-9B4F-397A9083D5BC}

Figs 11, 29, 49, 67

\section{Diagnosis}

Cautires katarinae sp. nov. is similar to $C$. griseus in the reddish pubescence on the humeral part of the elytra and the shape of the pronotum. It differs in the shape of antennal lamellae (Figs 9, 11). Additionally, C. katarinae sp. nov. has the robust phallus with the obtuse apex (Fig. 67).

\section{Etymology}

The specific epithet is in honour of Katerina Sklenarova, a colleague from the laboratory.

\section{Type material}

\section{Holotype}

MALAYSIA: ${ }^{\Uparrow}$, Kelantan, km 12, Road Kg. Raja-Gua Musang, 980 m, 4³8'15" N, 101³0'11" E, 20 Apr. 2013 (AJ0028).

\section{Measurements}

BL $8.1 \mathrm{~mm}$, PL $1.5 \mathrm{~mm}$, PW $1.65 \mathrm{~mm}$, HW $1.05 \mathrm{~mm}$, Edist $0.51 \mathrm{~mm}$, Ediam $0.66 \mathrm{~mm}$, LP $1.1 \mathrm{~mm}$.

\section{Description of the male}

Body slender, mostly black, primary and secondary elytral costae with reddish pubescence, only posterior part of costae black (Fig. 49). Head small, eyes hemispherically prominent, large, eye diameter 1.29 times interocular distance. Antennae robust, flabellate, lamellae wide and flat (Fig. 11). Pronotum with 7 areolae, median areola well developed, marked by sharp ridges, median areola attached directly to basal margin of pronotum; anterior pronotal angles obtuse, lateral margins straight, lateral part of pronotum elevated, only slightly divergent, posterior angles prominent, but not acutely projected, pronotum with red pubescence (Fig. 29). Elytra parallel-sided, very slightly widened apically, primary and secondary costae well developed, transverse costae dense (Fig. 49). Phallus robust, widened from basal to apical fifth, slightly constricted in middle of widened part, widely rounded at apex (Fig. 67).

\section{Distribution}

Peninsular Malaysia: Kelantan. The species is known only from the type locality.

Cautires kirstenae sp. nov. urn:1sid:zoobank.org:act:82953FF5-3CB3-40FB-8E92-4454E29C5A15

Figs 12, 30, 50, 68

\section{Diagnosis}

Cautires kirstenae sp. nov. belongs to the species with a uniformly black body. It is similar to C. communis sp. nov. and $C$. jasarensis sp. nov., but differs from $C$. communis sp. nov. in the long and slender male antennal lamellae (Figs 8, 12) and from $C$. jasarensis sp. nov. in the more slender phallus (Figs 66, 68).

\section{Etymology}

The specific epithet kirstenae is a matronym in honour of Kirsten Miller, a colleague from the Natural History Museum in London. 


\section{Type material}

\section{Holotype}

MALAYSIA: §̊, Pahang, Tanah Rata, 1600 m, 3-20 Feb. 2005 (VK0419).

\section{Measurements}

BL 11.7 mm, PL 1.5 mm, PW 2.2 mm, HW 1.2 mm, Edist 0.72 mm, Ediam 0.59 mm, LP 1.66 mm.

\section{Description of the male}

Body uniformly black (Fig. 50). Head small, eyes hemispherically prominent, eye diameter 0.82 times interocular distance. Antennae flabellate, lamella of antennomere 3 about 2.5 longer than stem of antennomere (Fig. 12). Pronotum with 7 areolae, fronto- and postero-lateral ridges obtuse, inconspicuous, only median areola complete, marked by well developed ridges, median areola attached directly to basal margin; anterior angles obtuse, lateral margins slightly concave, lateral part of pronotum elevated, posterior angles sharply prominent (Fig. 30). Elytra parallel-sided, primary and secondary costae well developed, transverse costae dense, reticulate cells regular (Fig. 50). Phallus very slender, only slightly widened in apical fourth, pointed at apex (Fig. 68).

\section{Distribution}

Peninsular Malaysia: Pahang. The species is known only from the type locality.

Cautires kotatinggensis sp. nov. urn:1sid:zoobank.org:act:5586C104-301B-4C4A-A772-9849A7E3E2A2

Figs 13, 31, 51, 69

\section{Diagnosis}

Cautires kotatinggensis sp. nov. resembles $C$. alexae sp. nov. and $C$. arribasae sp. nov. in the bright humeral part of the elytra and the black pronotum. Additionally, all these species differ in the shape of the pronotum (Figs 21, 23, 31) and the shape of their phalli (Figs 59, 61, 69).

\section{Etymology}

The specific epithet refers to the town Kota Tinggi, a place close to the locality where the paratype was collected.

\section{Type material}

\section{Holotype}

MALAYSIA: §̊, Perak, km 24, Road Tapah-Ringlet, 350 m, 4¹8'39" N, 101¹9'52" E, 19 Apr. 2013 (AJ0048).

\section{Paratypes}

MALAYSIA: 1, 1 , same data as the holotype (AJ0042, AJ0048).

\section{Measurements}

BL 6.5 mm, PL 1.1 mm, PW 1.5 mm, HW 0.85 mm, Edist 0.44 mm, Ediam 0.44 mm, LP $1.1 \mathrm{~mm}$.

\section{Description of the male}

Body slender, black, except basal half of primary and secondary elytral costae bearing reddish pubescence (Fig. 51). Head small, eyes hemispherically prominent, quite large, eye diameter 1.0 times interocular distance. Antennae flabellate, with moderately long antennae (Fig. 13). Pronotum with 5 
areolae, postero-lateral ridges absent, median areola complete, well developed, attached directly to basal margin of pronotum; anterior angles obtuse, lateral margins straight, strongly elevated, posterior angles prominent, pronotal margins and costae with brown pubescence (Fig. 31). Elytra parallel-sided, primary and secondary costae well developed, transverse costae dense, minute (Fig. 51). Phallus slender, wide, spoon-shaped in apical part, obtuse apically (Fig. 69).

\section{Distribution}

Peninsular Malaysia: Perak, Johor. Cautires kotatinggensis sp. nov. is one of a few widely distributed Cautires species in the Malay Peninsula.

\section{Cautires linardi sp. nov. urn:1sid:zoobank.org:act:30D4C7CB-4F8D-4176-A2D0-8E3050A8CB32}

Figs $14,32,52,70$

\section{Diagnosis}

Cautires linardi sp. nov. belongs to the group with the uniformly black body and large eyes. This species has the characteristic shape of the pronotum with the very wide basal part and acutely projected posterior angles (Fig. 32).

\section{Etymology}

The specific epithet linardi is a patronym in honour of Benjamin Linard, a colleague from the Natural History Museum in London.

\section{Type material}

\section{Holotype}

MALAYSIA: ${ }^{\lambda}$, Pahang, Mt. Jasar, N slope, 1550 m, 4²8'56" N, 101²1'55" E, 11 Apr. 2013 (AJ0005).

\section{Paratypes}

MALAYSIA: 1 q, Pahang, Tanah Rata, 24-31 Jan. 2003 (VK0451); 1 +, Malaysia, Pahang, Tanah Rata, 1-13 Feb. 2003 (VK0625).

\section{Measurements}

BL 11.6 mm, PL 1.7 mm, PW 2.5 mm, HW 1.15 mm, Edist 0.66 mm, Ediam $0.71 \mathrm{~mm}$, LP $2.12 \mathrm{~mm}$.

\section{Description of the male}

Body uniformly black (Fig. 52). Head small, eyes hemispherically prominent, quite large, eye diameter 1.08 times interocular distance. Antennae flabellate with lamella of antennomere 6 about three times longer than stem of antennomere (Fig. 14). Pronotum transverse, about twice wider than long at midline, with 7 areolae, only postero-lateral ridges weaker, obtuse; median areola complete, well developed, attached directly to basal margin; anterior angles obtuse, lateral margins concave, lateral part of pronotum strongly elevated, posterior angles slender, acutely prominent (Fig. 32). Elytra parallel-sided, primary and secondary costae well developed, transverse costae dense, irregular (Fig. 52). Phallus very slender, only slightly wider in apical part, obtuse at apex (Fig. 70).

\section{Distribution}

Peninsular Malaysia: Pahang. 


\section{Cautires maseki sp. nov. urn:1sid:zoobank.org:act:653D5519-1C19-4526-ABC2-373B1484A6F2}

Figs $15,33,53,71$

\section{Diagnosis}

Cautires maseki sp. nov. is one of numerous species with a uniformly black body. It is very similar to $C$. nervosus and $C$ simillimus sp. nov. in general appearance and these species differ only in the shape of the phallus, which is extremely robust in $C$. maseki sp. nov. (Figs 71, 73, 76).

\section{Etymology}

The specific name is in honour of Michal Masek, a colleague from the laboratory.

\section{Type material}

\section{Holotype}

MALAYSIA: 고, Pahang, Gn. Beremban, 1480 m, 4²7'51" N, 101²3'26" E, 6-28 Apr. 2013 (AJ0069).

\section{Additional material examined}

MALAYSIA: 1 +, Pahang, Tanah Rata, 1500-1800 m, 2-26 Feb. 2004 (VK0280); 1 ô, Pahang, Tanah Rata, 1-13 Feb. 2003 (VK0628).

\section{Measurements}

BL 9.8 mm, PL 1.25 mm, PW 1.75 mm, HW 1.0 mm, Edist 0.57 mm, Ediam 0.44 mm, LP 1.45 mm.

\section{Description of the male}

Body uniformly black (Fig. 53). Head small, eyes hemispherically prominent, small, eye diameter 0.77 times interocular distance. Antennae flabellate, with lamella of antennomere 6 about twice longer than stem of antennomere (Fig. 15). Pronotum with shining disc and with 7 well developed areolae, median areola complete, well marked, attached directly to basal margin of pronotum; anterior angles obtuse, lateral margins concave, almost parallel-sided in anterior half of pronotum, lateral part of pronotum strongly elevated, posterior angles slender, acutely prominent (Fig. 33). Elytra apparently widened apically, primary and secondary costae well developed, transverse costae dense, slightly irregular (Fig. 53). Phallus very robust, slender only at basal third, apex rather obtuse (Fig. 71).

\section{Distribution}

Peninsular Malaysia: Pahang.

Cautires pahangensis sp. nov. urn:1sid:zoobank.org:act:2616E587-EEC1-4C9E-90CD-F5D5F85793DB Figs 16, 34, 54, 72

\section{Diagnosis}

Cautires pahangensis sp. nov. is a mountain species with a bright pubescent humeral part of the elytra and a reddish pubescence on the pronotum. It has moderately long antennal lamellae (Fig. 16) and a slender phallus with a gradually widened part and a pointed apex (Fig. 72).

\section{Etymology}

The specific epithet refers to the Malay state Pahang where the holotype of $C$. pahangensis sp. nov. was collected. 
JIRUSKOVA A. et al., The genus Cautires in Malay mountain forests

\section{Type material}

\section{Holotype}

MALAYSIA: §̊, Pahang, Tanah Rata, 1600 m, 3-20 Feb. 2005 (VK0527).

\section{Measurements}

BL 9.3 mm, PL 1.15 mm, PW 1.75 mm, HW 1.0 mm, Edist 0.53 mm, Ediam 0.58 mm, LP 1.49 mm.

\section{Description of the male}

Body quite slender, black, upper side bicoloured, pronotum orange, elytra black except basal fifth of primary and secondary elytral costae bearing orange pubescence (Fig. 54). Head small, eyes hemispherically prominent, quite large, eye diameter 1.09 times interocular distance. Antennae flabellate with moderately long lamellae (Fig. 16). Pronotal disc mat, with 7 areolae, median areola complete, but ridges forming median areola obtuse similarly to postero-lateral ridges, median areola attached directly to basal margin of pronotum; anterior angles obtuse, lateral margins slightly concave, lateral part of pronotum strongly elevated, posterior angles robust but prominent (Fig. 34). Elytra apparently widened apically, primary and secondary costae well developed, transverse costae dense (Fig. 54). Phallus moderately robust, widest in apical third, slightly pointed at apex (Fig. 72).

\section{Distribution}

Peninsular Malaysia: Pahang. This species is known in a single specimen only.

Cautires nervosus Kleine, 1926

Figs 17, 35, 55, 73

Cautires nervosus Kleine, 1926: 187.

\section{Diagnosis}

Cautires nervosus is one of the uniformly black coloured species (Figs 35, 55). The species has extremely small male eyes, their diameter only 0.54 times the interocular distance, and a very short antennal lamella of antennomere 3 (Fig. 17). The phallus of C. nervosus is moderately wide (Fig. 73) and differs from the similar phalli of C. maseki sp. nov. and C. simillimus sp. nov. (Figs 71, 76).

\section{Type material}

\section{Syntypes}

MALAYSIA: 1 §, Pahang, Cameron Highlands, Tanah Rata, 4800 ft., 13 Mar. 1924; 1 §, same locality, Rhododendron Hill, 5200 ft., 22 Jun. 1923; 1 J, Lubok Tamang, 3500 ft., 11 Mar. 1924, all specimens H.M. Pendlebury leg. (BMNH).

\section{Additional material examined}

MALAYSIA: 2 ठో, Pahang, Tanah Rata, 1500-1800 m, 2-26 Feb. 2004 (VK0516, VK0517); 12 우, Pahang, Tanah Rata, 1500-1800 m, 2-26 Feb. 2004 (VK0241, VK0243, VK0257, VK0258, VK0266, VK0273, VK0281, VK0282, VK0318, VK0319, VK0518, VK0525); 3 우오, Pahang, Tanah Rata, 1600 m, Cameron Highl., 3-20 Feb. 2005 (VK0570, VK0573, VK0576); 1 ô, 3 q $q$, Pahang, Tanah Rata, 1600 m, Cameron Highl., 3-20 Feb. 2005 (VK0360, VK0422, VK0533, VK0571); 1 +, Pahang, Gn. Jasar, E

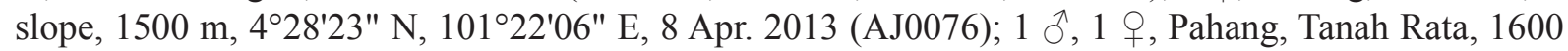
m, Gn. Jasar, 3-9 Feb. 2005 (VK0618, VK0621); 1 ㅇ, Pahang, Tanah Rata, 24-31 Jan. 2003 (VK0269,

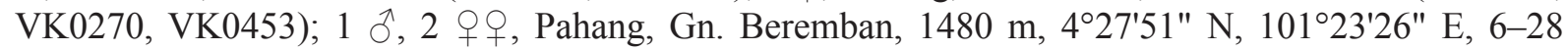
Apr. 2013 (AJ0010, AJ0065, AJ0080); 1 गे, Pahang, Brinchang, Gn. Brinchang, 1800 m, 4³0'34" N, 101²3'09" E, 12-16 Apr. 2013 (AJ0085, AJ0086); 2 우, Pahang, Tanah Rata, 1600 m, Gn. Jasar, 3-9 
Feb. 2005, Bolm leg. (VK0566, VK0567); 1 Oૈ, Pahang, Tanah Rata, Gn. Jasar, 1600 m, 3 Jan. 2005 (VK0250).

\section{Measurements}

BL 8.9 mm, PL 1.5 mm, PW 1.75 mm, HW $1.1 \mathrm{~mm}$, Edist $0.61 \mathrm{~mm}$, Ediam $0.33 \mathrm{~mm}$, LP $1.76 \mathrm{~mm}$.

\section{Distribution}

Peninsular Malaysia: Pahang. Cautires nervosus is a very common species in the Cameron Highlands area, but no specimens were recorded outside the Cameron Highlands plateau and adjacent mountain tops with elevation over $1400 \mathrm{~m}$ a.s.l.

\section{Cautires renatae sp. nov. urn:1sid:zoobank.org:act:FC371A58-9CB9-4581-9A86-AB6DF50B8BB9}

Figs 18, 36, 56, 74

\section{Diagnosis}

Cautires renatae sp. nov. resembles $C$. reverandi in the bright humeral part of elytra and the reddish pubescence on the pronotum (Figs 36-37). Additionally, C. renatae sp. nov. has a different shape of the phallus (Figs 74-75).

\section{Etymology}

The specific name is in honour of Renata Bilkova, a colleague from the laboratory.

\section{Type material}

\section{Holotype}

MALAYSIA: đ̃, Kelantan, km 12, Road Kg. Raja-Gua Musang, 980 m, 4³8'15" N, 101³0'11" E, 20 Apr. 2013 (AJ0035).

\section{Paratype}

MALAYSIA: $1 \partial^{\lambda}$, same locality data as the holotype (AJ0027).

\section{Measurements}

BL 7.6 mm, PL 1.2 mm, PW 1.55 mm, HW 0.85 mm, Edist 0.41 mm, Ediam 0.55 mm, LP $1.1 \mathrm{~mm}$.

\section{Description of the male}

Body slender, black, pronotum with orange pubescence, elytra mostly black, only basal third of primary and one fourth of secondary elytral costae with orange pubescence (Fig. 56). Head small, eyes hemispherically prominent, large, eye diameter 1.34 times interocular distance. Antennae flabellate, lamella of antennomere 3 slightly more that 1.5 length of antennomere length (Fig. 18). Pronotum with seven areolae, posterior costae sharp in lateral part and obtuse in middle of pronotum, median areola complete, well-marked, attached directly to basal margin; anterior angles obtuse, lateral margins concave, strongly elevated, posterior angles strongly prominent, (Fig. 36). Elytra parallel-sided, secondary costae developed, transverse costae dense (Fig. 56). Phallus robust, constricted in middle part, obtuse at apex (Fig. 74).

\section{Distribution}

Peninsular Malaysia: Kelantan. Cautires renatae sp. nov. is known only from the type locality in the Kelantan state. 
Cautires reverandi Pic, 1925

Figs 19, 37, 57, 75

Cautires reverandi Pic, 1925: 9.

\section{Diagnosis}

Cautires reverandi belongs to a group of species with a bright humeral part of the elytra (Fig. 57), a reddish pubescence on the pronotum (Fig. 37) and big eyes. It differs from the superficially similar species $C$. renatae sp. nov. in the shorter lamella of the antennomere 3 (Figs 18-19) and in the very wide phallus (Figs 74-75).

\section{Type material}

\section{Holotype}

MALAYSIA: + , Penang (without further data, MHNP).

\section{Additional material examined}

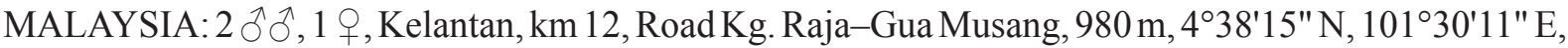
20 Apr. 2013 (AJ0029-31); 2 우우, Pahang, Kg Kuala Boh, 1040 m, 4²6'25" N, 101²8'14" E, 18 Apr. 2013 (AJ0018, 24); 1 Ô, Perak, Banjaran Titiwangsa, Ringlet, 900 m, 29 Mar.-15 Apr. 2004 (VK0430); 1 , Pahang, $30 \mathrm{~km} \mathrm{NE}$ of Raub, $600 \mathrm{~m}$ (LB0178).

\section{Measurements}

BL 8.3 mm, PL 1.4 mm, PW 1.7 mm, HW 1.0 mm, Edist 0.5 mm, Ediam 0.6 mm, LP $1.1 \mathrm{~mm}$.

\section{Distribution}

Peninsular Malaysia: Perak, Pahang, Kelantan. Cautires reverandi is a widely distributed species in the Cameron Highlands region.

\section{Remark}

The holotype of $C$. reverandi is a female and the comparison with other species is limited to the general appearance. We identified a series of very similar specimens from several localities in the lowlands and lower mountain forests in the region, which we identified as $C$. reverandi. Our association of the female type and the newly collected individual from Malay inland as the same species is additionally supported by a common occurrence in the region.

Cautires simillimus Kleine, 1926

Figs 20, 38, 58, 76

Cautires simillimus Kleine, 1926: 187.

\section{Diagnosis}

Cautires simillimus belongs to a group of mountain species with a uniformly black body (Figs 38, 58). This species resembles $C$. nervosus and $C$. maseki sp. nov. in the general appearance, but the males of $C$. simillimus have long and slender antennal lamellae (Fig. 20) and additionally they differ in the relatively robust, parallel-sided phallus (Fig. 76).

\section{Type material}

\section{Holotype}

MALAYSIA: + , Pahang, Lubok Tamang, 3500 ft., 10 Jun. 1923, H.M. Pendlebury (BMNH). 


\section{Additional material examined}

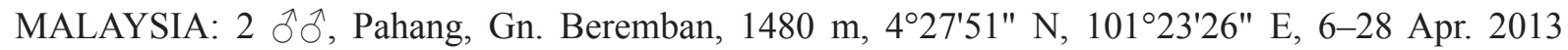

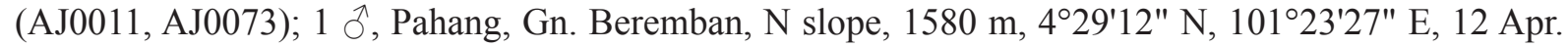
2013 (AJ0090); 2 ふึ ô, 1 ㅇ, Pahang, Tanah Rata, 1500-1800 m, 2-26 Feb. 2004 (VK0247, VK0259, VK0283); 1 ô, Pahang, Tanah Rata, 1400-1650 m, 4-11 Apr. 2005 (VK0309); 2 우, Pahang, Tanah Rata, 1600 m, Cameron Highlands, 3-20 Feb. 2005 (VK0574, VK0620); 1 ○े, Ringlet (MM0005).

\section{Measurements}

BL 7.0 mm, PL 1.1 mm, PW 1.5 mm, HW 1.0 mm, Edist 0.50 mm, Ediam 0.45 mm, LP 0.9 mm.

\section{Distribution}

Peninsular Malaysia: Pahang. The species occurs exclusively in the high mountains in the Cameron Highlands.

\section{Remark}

The identity of this species is based on the general appearance, which might be misleading in some cases, but with a female designated as the holotype we do not have any other possibility for identification. The newly identified specimens were collected in the type locality and the species is common in the Cameron Highlands.

Cautires selangorensis Kleine, 1930

Fig. 77

Cautires selangorensis Kleine, 1930b: 170.

\section{Diagnosis}

Cautires selangorensis belongs to a group of species with at least the basal part of the elytra covered with a red pubescence. It differs from the similarly coloured species in the relatively slender phallus, which is widest in the apical two fifths of its length (Fig. 77).

\section{Type material}

\section{Holotype}

MALAYSIA: đ̊, Malay Peninsula, Selangor, Kuala Lumpur, 21 Jul. 1929, H.M. Pendlebury leg. (BMNH).

\section{Redescription of the male}

Body slender, black, only basal third elytral costae with reddish pubescence. Head small, antennae flabellate, with lamellae of antennomeres 7-9 about twice longer than respective stems. Pronotum with 7 areolae, postero-lateral costae sharp, well-developed, conspicuous, median areola complete, sharp with elevated margins, areola attached directly to basal margin; anterior angles obtuse, lateral margins concave in the posterior part, posterior angles sharply prominent, pronotum covered with black pubescence. Elytra parallel-sided, secondary costae developed, transverse costae dense. Phallus slender, widest in apical two fifths, apex slender, long $1.2 \mathrm{~mm}$ (Fig. 77).

\section{Distribution}

This species is known only from the type locality in the Selangor state. Although a wide distribution is expected as in other lowland species, these habitats are heavily affected by urban development and palm oil production and the species has not been recorded since its description. 
Cautires tenebricus Kleine, 1926

Fig. 78

Cautires tenebricus Kleine, 1926: 96.

\section{Diagnosis}

Cautires tenebricus belongs to a group of mountain species with a uniformly black body. This species resembles $C$. nervosus and $C$. maseki sp. nov. in general appearance, but the male genitalia are characteristic in the slender phallus with the widened apical third (Fig. 78).

\section{Type material}

\section{Holotype}

MALAYSIA: ${ }^{\lambda}$, Perak, Doherty (BMNH).

\section{Measurements}

BL 7.0 mm, PL 1.05 mm, PW 1.35 mm, HW 1.0 mm, LP 0.9 mm.

\section{Distribution}

Peninsular Malaysia: Perak.

\section{Remark}

Cautires tenebricus has not been found in the recently collected material from the Malay Peninsula and the only known specimen is the holotype deposited in the Museum of Natural History in London.

\section{Cautires congener Waterhouse, 1879}

Cautires congener Waterhouse, 1879: 36.

\section{Type material}

\section{Holotype}

INDONESIA: $\widehat{\jmath}$, Java (BMNH); no further data available.

\section{Remark}

Kleine (1926) reported C. congener from several localities in the Malay Peninsula and illustrated the apical part of the phallus of a specimen. We studied the holotype of $C$. congener, deposited in the BMNH collection, and found that Kleine's identification was incorrect. The holotype has the apical part of the phallus much wider and the species is yellowish orange coloured unlike all Malay Cautires species. Kleine (1926) reported several specimens from various localities from the lowlands to the lower mountain elevations in the Cameron Highlands. These specimens were not available for our study, but they probably do not represent $C$. congener, which is known only from Java.

\section{Discussion}

Tropical mountains have been identified as regions with high diversity and endemism (e.g., Toussaint et al. 2014; Merckx et al. 2015), and in our study we also demonstrate the occurrence of a high number of Cautires species in the limited mountain area of the Main Range of the Malaysian Peninsula. We suppose that these species evolved in the region as they do not occur anywhere else. Altogether, fourteen new Cautires species have been added in this contribution to the seven species originally known from the Malay Peninsula and the ten species of the Cautires obsoletus group reviewed earlier (Jiruskova \& 
Bocak 2015). The total number of Cautires in the Malay Peninsula has reached 30 species (Fig. 79). The altitudinal distribution shows a very high diversity in the Main Range and twenty-one species have been reported from the humid and relatively cold mountain forests in the Cameron Highlands plateau and the adjacent mountain tops with altitudes $>1000 \mathrm{~m}$ a.s.l. Only two species were collected in the intermediate elevations $600-1000 \mathrm{~m}$ a.s.l. and they overlap in distribution with the mountain species from elevations around $1000 \mathrm{~m}$ a.s.l. Additionally, six species were collected in the lowlands of the Malay Peninsula, i.e., elevations under $400 \mathrm{~m}$ a.s.l., and, finally, only a single species, $C$. indus, has a wide altitudinal distribution and this is the only species which was also reported from Sumatra. The proportion of lowland species is higher in the C. obsoletus species group as defined by Dudkova \& Bocak (2010). The fauna of the mountain regions is mostly represented by species with a fully developed pattern of seven areolae in the pronotum. We noted that none of the species occurs in the wide span of different ecosystems from the lowlands to the high mountains and that a low number of species have been recorded from the intermediate to lower mountain elevations 600-800 m a.s.l. (Fig. 79).

Numerous black coloured species occur in the mountain forest at elevation over $1000 \mathrm{~m}$ a.s.l. (Fig. 79). Although some species with bright colour pattern have been collected in the mountain habitats, we noted that the black individuals dominated the mountain ecosystem and the brightly coloured individuals were only rarely collected from among them. The black species are restricted to elevations over $1000 \mathrm{~m}$ a.s.l. and we suggest that differences in mimicry patterns might play a role in the evolution of the mountain species. Membership in different aposematic rings has been found to be a factor limiting the gene flow in other organisms (e.g., Merrill et al. 2014; Twomey et al. 2014).

The favourable wet conditions are another factor which potentially contributes to the observed diversity in the higher elevations. The larvae of net-winged beetles have unique mandibles adapted for sucking liquids from decaying organic material (Bocak \& Matsuda 2003) and they need very moist organic material to be able to feed throughout the year. The mountain area has a similar amount of precipitation to the lowlands west of the range, around $2600 \mathrm{~mm}$ per year, but further moisture occurs in mountain forests through condensation from clouds and lower evaporation. This is because the roughly $10^{\circ} \mathrm{C}$ lower temperature results in the absence of a clear dry season in the high elevations (data from the www.worldclimate.com database). The amount of organic debris on the soil surface is higher and the net-winged beetles are very common in these mountain localities. The larvae of Cautires have been collected from decaying twigs in the mountains of Sumatra (Bocak \& Matsuda 2003) and sifted from soil surface wood debris in the Cameron Highland area (unpublished data).

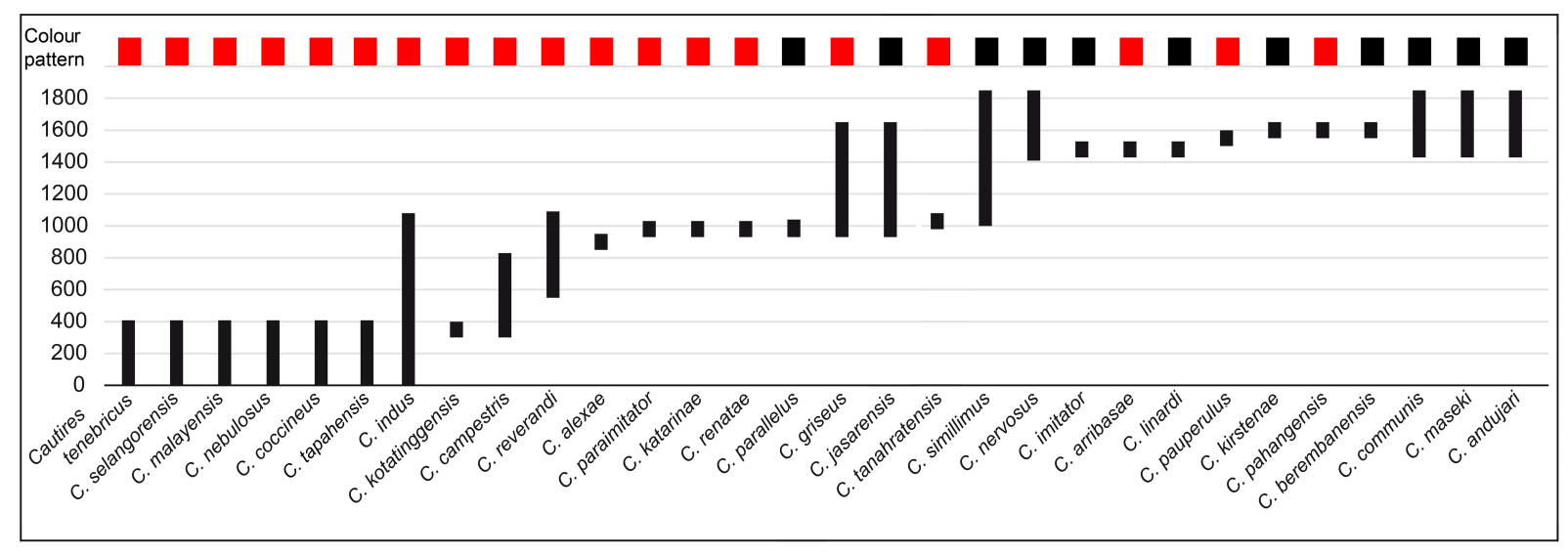

Fig. 79. The altitudinal zonation of the Cautires species occurring in the Malay Peninsula. 
The comparison of a relatively high number of Cautirina sequences reported in the previous study on phylogeny of Metriorrhynchini (Sklenarova et al. 2013) indicates that the Oriental species of Cautires have small ranges. The uniqueness of the Malay fauna was confirmed by the extensive search in the historical collections of the Oriental region in the museums of Paris, Warsaw and London, where the most important collections are deposited. We noted during this study that only a single species, $C$. indus, has been recorded in the Malay Peninsula and simultaneously in neighbouring Sumatra and Borneo. The other species was reported from Malaysia and Java due to incorrect identification (Kleine 1926; C. congener). This finding agrees with the low dispersal propensity of net-winged beetles. In contrast with them, the fauna of many beetle families is similar on both sides of the shallow Malacca Strait which was dry for the substantial part of the Quaternary (Sathiamurthy \& Voris 2006). The described high diversity, almost complete turnover between major regions and high level of endemism call for the protection of the unique faunas in the Malay mountains.

\section{Acknowledgements}

We are obliged to all colleagues for their help during our visits in the collections under their care: M. Barclay, H. Mendel and M. Geiser (London), T. Deuve and A. Taghavian (Paris), and W. Tomaszewska and T. Huflejt (Warszawa). We are sincerely grateful to all colleagues, who provided us with the material for this study. Timothy C. Bray critically read the manuscript prior to its submission. This work was supported by the Czech Science Foundation (grant P506/11/1757 to LB) and the Palacký University (PrF2015-018 to AJ and MM).

\section{References}

Bocak L. 2000. Revision of the genus Wakarumbia (Coleoptera: Lycidae). European Journal of Entomology 97: 271-278. http://dx.doi.org/10.14411/eje.2000.043

Bocak L. 2002. Generic revision and phylogenetic analysis of the Metriorrhynchinae (Coleoptera: Lycidae). European Journal of Entomology 99: 315-351. http://dx.doi.org/10.14411/eje.2002.043

Bocak L. \& Matsuda K. 2003. Review of immature stages of the family Lycidae (Insecta: Coleoptera). Journal of Natural History 37: 1463-1507. http://dx.doi.org/10.1080/00222930210125362

Bocek M. \& Bocak L. 2016. Species limits in polymorphic mimetic Eniclases net-winged beetles from New Guinean mountains (Coleoptera, Lycidae). ZooKeys 593: 15-35. http://dx.doi.org/10.3897/ zookeys.593.7728

Bourgeois J.M. 1891. Études sur la distribution géographique des Malacodermes. I. Lycides. Annales de la Societé entomologique de France 60: 337-364. Available from http://biodiversitylibrary.org/ page/32547697 [accessed 6 Jul. 2016]

Dudkova P. \& Bocak L. 2010. A review of the Cautires obsoletus species group from Indo-Burma (Coleoptera: Lycidae). Zootaxa 2527: 28-48.

Jiruskova A. \& Bocak L. 2015. Species delimitation in Cautires (Coleoptera: Lycidae) from Peninsular Malaysia using DNA data and morphology. Annales Zoologici 65: 239-248. http://dx.doi.org/10.3161/ 00034541ANZ2015.65.2.007

Kirsch T. 1875. Neue Käfer aus Malakka. Mitteilungen aus dem Dresdener Museum 1: 25-28.

Kleine R. 1926. Lycidae in the collection of the Federated Malay States museums at Kuala Lumpur. Journal of the Federal Malay States Museum 13: 177-197.

Kleine R. 1930a. Neue Lycidae aus dem indischen Gebiet. Stettiner Entomologische Zeitung 91: 94-103.

Kleine R. 1930b. Neue Lyciden der Malaiischen Subregion. Journal of the Federal Malay State Museum 16: 169-174. 
Kleine R. 1933. Lycidae. Coleopterorum Catalogus auspiciis et auxilio, Pars 128, Lycidae. W. Junk editus S. Schenkling, Berlin.

Li Y., Gunter N., Pang H. \& Bocak L. 2015. DNA-based species delimitation separates highly divergent populations within morphologically coherent clades of poorly dispersing beetles. Zoological Journal of the Linnean Society 175 (1): 59-72. http://dx.doi.org/10.1111/zoj.12262

Masek M., Palata V., Bray T.C. \& Bocak L. 2015. Molecular phylogeny reveals high diversity and geographic structure in Asian neotenic net-winged beetles Platerodrilus (Coleoptera: Lycidae). PlosOne 10 (4): e0123855. http://dx.doi.org/10.1371/journal.pone.0123855

Merckx V.S.F.T., Hendriks K.P., Beentjes K.K., Mennes C.B., Becking L.E., Peijnenburg K.T.C.A., Afendy A., Arumugam N., de Boer H., Biun A., Buang M.M., Chen P.P., Chung A.Y.C., Dow R., Feijen F.A.A., Feijen H., Soest C.F.V., Geml J., Geurts R., Gravendeel B., Hovenkamp P., Imbun P., Ipor I., Janssens S.B., Jocque M., Kappes H., Khoo E., Koomen P., Lens F., Majapun R.J., Morgado L.N., Neupane S., Nieser N., Pereira J.T., Rahman H., Sabran S., Sawang A., Schwallier R.M., Shim P.S., Smit H., Sol N., Spait M., Stech M., Stokvis F., Sugau J.B., Suleiman M., Sumail S., Thomas D.C., van Tol J., Tuh F.Y.Y., Yahya B.E., Nais J., Repin R., Lakim M. \& Schilthuizen M. 2015. Evolution of endemism on a young tropical mountain. Nature 524: 347-350. http://dx.doi.org/10.1038/nature14949

Merrill R.M., Chia A. \& Nadeau N.J. 2014. Divergent warning patterns contribute to assortative mating between incipient Heliconius species. Ecology and Evolution 4: 911-917. http://dx.doi.org/10.1002/ $\underline{\text { ece3.996 }}$

Pic M. 1925. Malacodermes exotiques. L'Echange 420: 8-12.

Riedel A., Sagata K., Suhardjono Y.R., Tänzler R. \& Balke M. 2013. Integrative taxonomy on the fast track - towards more sustainability in biodiversity research. Frontiers in Zoology 10: 15. http://dx.doi. org/10.1186/1742-9994-10-15

Sathiamurthy E. \& Voris H.K. 2006. Maps of Holocene sea level transgression and submerged lakes on the Sunda shelf. The Natural History Journal of Chulalongkorn University Suppl. 2: 1-43.

Sklenarova K., Chesters D. \& Bocak L. 2013. Phylogeography of poorly dispersing net winged beetles: a role of drifting India in the origin of Afrotropical and Oriental fauna. PlosOne 8 (6): e67957. http:// dx.doi.org/10.1371/journal.pone.0067957

Sklenarova K., Kubecek V. \& Bocak L. 2014. Subtribal classification of Metriorrhynchini (Insecta: Coleoptera: Lycidae): an integrative approach using molecular phylogeny and morphology of adults and larvae. Arthropod Systematics and Phylogeny 72: 37-54.

Toussaint E.F.A., Hall R., Monaghan M.T., Sagata K., Ibalim S., Shaverdo H.V., Vogler A.P., Pons J. \& Balke M. 2014. The towering orogeny of New Guinea as a trigger for arthropod megadiversity. Nature Communications 5: 4001. http://dx.doi.org/10.1038/ncomms5001

Twomey E., Vestergaard J.S. \& Summers K. 2014. Reproductive isolation related to mimetic divergence in the poison frog Ranitomeya imitator. Nature Communications 5: 4749. http://dx.doi.org/10.1038/ ncomms5749

Waterhouse C.O. 1878. On the different forms occurring in the Colepterous family Lycidae, with descriptions of new genera and species. Transaction of the Entomological Society of London 1: 95-118. Available from http://biodiversitylibrary.org/page/12552290 [accessed 6 Jul. 2016]

Waterhouse C.O. 1879. Illustration of the Typical Specimens of Coleoptera in the Collection of the British Museum. Part I. Lycidae. British Museum, London. 
Weiszenstein M. \& Bocak L. 2011. A review of the genus Metanoeus from Philippines (Coleoptera: Lycidae). Raffles Bulletin of Zoology 59: 163-170.

Manuscript received: 8 January 2016

Manuscript accepted: 16 March 2016

Published on: 5 August 2016

Topic editor: Gavin Broad

Desk editor: Kristiaan Hoedemakers

Printed versions of all papers are also deposited in the libraries of the institutes that are members of the EJT consortium: Muséum national d'Histoire naturelle, Paris, France; Botanic Garden Meise, Belgium; Royal Museum for Central Africa, Tervuren, Belgium; Natural History Museum, London, United Kingdom; Royal Belgian Institute of Natural Sciences, Brussels, Belgium; Natural History Museum of Denmark, Copenhagen, Denmark; Naturalis Biodiversity Center, Leiden, the Netherlands. 